\author{
Board of Governors of the Federal Reserve System \\ International Finance Discussion Papers \\ Number 419 \\ December 1991
}

A PRIMER ON THE JAPANESE BANKING SYSTEM

Allen B. Franke1 and Paul B. Morgan

NOTE: International Finance Discussion Papers are preliminary materials circulated to stimulate discussion and critical comment. References in publications to International Finance Discussion Papers (other than an acknowledgment: that the writer has had access to unpublished material) should be cleared with the author or authors. 


\section{ABSTRACT}

This paper examines the effects of the liberalization of the Japanese financial system in the past twenty years. The changes are viewed in terms of their current and potential future impact on the Japanese banking industry. The purpose of this paper is to provide a discussion of the situation facing the banking system during the present transition period between the highly segmented and regulated financial system of the post-war high growth period, and the liberalized, financially deregulated environment toward which the Japanese regulatory authorities aspire. 


\title{
A Primer on the Japanese Banking System
}

\author{
Allen B. Frankel and Paul B. Morgan ${ }^{1}$
}

\section{Section I. Introduction}

In the past fifteen years, the Japanese financial system has undergone significant liberalization measures which have aimed at modernizing the financial intermediation process and irnproving the efficiency of Japanese corporate financing. The developments have stemmed largely from pressures external to the domestic banking sector itself, such as the Japanese government deficits of the 1970s, competition from international financial markets, and the new emphasis on capital management. These factors have led increasingly to fundamental changes in the system of finance in Japan, the objectives on which Japanese bankers place primary importance, and the competitive position of the banking system vis-a-vis the interrational sector and the domestic non-bank financial sector.

The purpose of this paper is to provide a discussion of the situation facing the banking system during the present transition period between the highly segmented and regulated financial system of the post-war high growth period, and the liberalized, financially deregulated environment toward which Japanese authorities aspire. Chart 1 outlines the primary factors that will be presented in our attempt to describe the process of change in the Japanese banking system. Each of the factors in the chart has fundamentally influenced the liberalization effort in Japan, and a discussion of the linkages among the various influences and the results of the events to date will help us to ascertain a picture of the current state of the banking industry in Japan.

1. The authors are staff members of the Division of International Finance. This paper represents the views of the authors and should not be interpreted as reflecting the views of the Board of Giovernors of the Federal Reserve System or other members of its staff. This is a revised version of a paper presented at a Federal Reserve System conference on international economic analysis in Philadelphia in October 1991. We would like to thank Larry Promisel, Hesna Genay, and conference participants for useful comments and suggestions. 
Section II provides a discussion of the evolution of Japan's financial system in the 1970s and early 1980s, with particular emphasis on the effects of the substantial increase in government debt during the decade as a result of changes in the flow of funds in Japan following the OPEC oil shocks. In addition, we briefly discuss the importance of the foreign exchange reforms of the early 1980 s.

In Section III, we begin with a description of the gradual deregulation of interest rates in Japan throughout the 1980s. Within this discussion, our focus is on the degree to which these reforms have affected the Japanese banking industry and have caused a rationalization of its modes of operation. Also reviewed in Section III are some of the various innovations and liberalizations in Japanese corporate financing practices during the 1980s, and the degree to which these factors have led to increased competition and shifts in customer base in the banking industry.

Section IV discusses the impact on Japanese banks of the adoption of the 1987 Basle Accord on Capital Adequacy. The section addresses the significant changes which the banks were forced to undergo in order to reach compliance with the capital standards. The impact of the extreme fluctuations in Japanese stock prices 1989 and 1990 on the capital positions of the banks is assessed as well.

Finally, Section $\mathrm{V}$ provides an outlook for further financial reform in Japan, given the current, weakened, state of the Japanese banks. While additional reform in the areas of interest rates, direct corporate financing, and financial market restructuring is guaranteed, the nature of the financial authorities' view toward maintaining consensus and stability throughout the deregulation process will be incorporated in a less ambitious timetable for further liberalization. 


\section{Section II. Evolution of Japan's financial System}

\section{Domestic}

Throughout most of the post-war period, the private Japanese financial system remained largely isolated from the rest of the world. The system was highly regulated. First, all interest rates were administratively set by the monetary authorities. This included bank deposit and lending rates, as well as coupon rates for government bonds and the debentures issued by long-term credit banks. Second, various types of banking firms and other financial service firms were legally and administratively confined to a specified range of activities assigned to each (see Chart 2 for an overview of the current structure). Third, securities markets were repressed, for example, through strict collateral requirements for the issuance of debt. Consequently, there were no real alternatives to bank financing for even the largest firms.

The access of Japanese financial firms to international financial markets has been restricted through exchange controls and limits on foreign activities. Until the 1970s, only a few financial firms, including foreign banks granted special concessions, were licensied to engage in foreign exchange transactions. The system of foreign exchange controls and licenses effectively separated Japanese domestic markets from financial markets abroad.

The OPEC oil shock in 1973 signalled a turning point in the operation of the Japariese financial system. In particular, the oil price shock ushered in a period of sizable government deficits. In turn, the persistent deficits were reflected in a buildup of Japanese government bonds to well over 40 percent of GNP by the mid-1980s compared with slightly more than 5 percent of GNP at the start of the buildup (see Chart 3). 
The buildup of Japanese government debt forced changes in the relationship between the Bank of Japan (BoJ) and members of the government bond underwriting syndicate. Traditionally, syndicate members had an understanding that the debt which they held in their portfolios would be repurchased by the BoJ at a purchase price set at such a level so as to avoid any losses on the original bond purchase. ${ }^{2}$ This arrangement for ex post compensation of losses by the BoJ can be described as similar to a look-back put option; ${ }^{3}$ it was similar in structure to stock compensation agreements employed by the major Japanese securities houses prior to 1991, in which corporate investors received a guaranteed minimum return on their investment, regardless of the actual stock market performance.

In the face of the mid-1970s surge in government debt issuance, Japanese monetary authorities concluded that the BoJ could no longer offer its generous rediscount facility for government debt without jeopardizing its ability to exert monetary control. ${ }^{4}$ The withdrawal of the Bank of Japan from the writing of put options to purchasers of Japanese government debt is evocative of the 1951 accord between the Federal Reserve and U.S.

2. Suzuki's commentaries on the implications for syndicate members of pre-1975 participation in government debt underwriting are particularly interesting. He concludes that underwriting of government debt, during the period of low administered rates, was not a source of adverse pressure from the viewpoint of either liquidity or profitability for syndicate members. See Suzuki, Yoshio. Money. Finance, and Macroeconomic Performance in Japan, Yale University Press, 1986, (pp. 19-20).

3. A look-back option captures the highest or lowest cash price during its term.

4. Shigehara describes the Bank of Japan's policy before 1975 as one in which the outright purchase of Japanese government bonds was generally kept in line with the trend increase in the monetary base. It should be noted that Japanese Law prohibits the Bank of Japan's direct subscription to new government bond issues. Shigehara, Kumiharu. "Iapan's Experience with Use of Monetary Policy and the Process of Liberalization," paper presented to the Pacific Region Central Banks' Conference on Domestic Monetary Policy sponsored by the Reserve Bank of Australia, October 12-13, 1990. 
Treasury from which the Federal Reserve received discretionary authority for monetary policy. ${ }^{5}$ Facing financial strains in the absence of the BoJ rediscount facility, the bond purchasing syndicate successfully lobbied in 1977 for permission to develop a secondary market. The syndicate members viewed the secondary market as a mechanism for the off loading of their holdings of seasoned bonds when called upon to purchase new debt. However, the syndicate process did not function smoothly over the period of large net issuance of government debt. In fact, over two periods in 1981 and 1982, syndicate participants publicly boycotted their underwriting responsibilities. ${ }^{6}$

The introduction of secondary market trading ended the extended postwar era of absolute administrative control of the structure of Japanese interest rates. In a related development, Japanese banks and securities companies were given formal authorization for the market-based funding mechanism for their bond purchases through short-term repurchase agreements, the gensaki market. The main investors in the gensaki market have been Japanese non-financial companies, some of whom have been, at times, undoubtedly exploiting the arbitrage opportunity to borrow at regulated rates in order to profit from the opportunity to invest at: higher market-rates. Japanese securities companies utilized the gensaki market to finance their inventories of bonds, and, in the process, greatly expanded the overall shares of Japanese government bonds that they collectively underwrote. ${ }^{7}$ Overall, in terms

5. Horvitz notes that, soon after the accord, long-term U.S. Government bond prices dropped below par for the first time since 1937. Horvitz, Paul. Monetary Policy and the Financial System, Prentice-Hall, Englewood Cliffs, New Jersey, 1983, pp. 508 - 511.

6. Suzuki (1986), Op. cit., p. 20.

7. In 1980, the securities companies were first permitted to offer money market mutual funds (chokuku), that were limited to holding medium-term Japanese government bonds. 
of adapting their financial structures to accommodate large government debt issues, the Japanese made choices of the same character as those made in other countries, namely, to permit limited disintermediation in order to support the underwriting of government: debt. ${ }^{8}$ However, available evidence supports the view that in the 1970s the Japanese authorities were reluctant reformers of their highly segmented financial system. Supporting this view is the fact that, until 1979, the banks were not permitted to issue yendenominated certificates of deposit (CDs), a source of non-earmarked market-rate financing. Chart 4 shows the outstanding amounts of various instruments in the Japanese domestic money markets from 1974 onward. It is not merely coincidental that the post-1984 surge in the growth of the Japanese domestic money market paralleled changes in the regulation of access of Japanese banks and companies to international markets. We will turn to a discussion of the interaction between domestic market reform and liberalized international access below. Through most of the postwar period, the Bank of Japan relied heavily on administration of its credit facilities for bank borrowers as a mechanism that enabled it to fulfill its monetary policy responsibilities. Japanese commercial banks were persistent borrowers from the Bank of Japan for the purpose of funding credit expansion, a so-called overborrowed position. In turn, the Bank made such funding conditional on a commercial bank's adherence to specific guidelines that governed their lending behaviors. The BoJ practice of window guidance of commercial banks' domestic credit activities persisted

8. For discussions of the role of government debt financing needs in a number of the industrial countries see Bank for International Settlements, Changes in the Organisation and Regulation of Capital Markets, Monetary and Economics Department of the Bank for International Settlements, Basle, 1987. 
until mid-1991, although in later years the practice is believed to have become more consultative.

In addition to the administrative guidance they received regarding their credit policies, the city banks' own capital raising efforts were limited by regulatory authorities. In 1983, the Japanese authorities first began to encourage city banks to differentiate themselves from one another with respect to stock market investors by permitting banks to take advantage of market-determined share prices. Chart 5 displays the share price behavior of Sumitomo Bank over the 1977-1986 period. Prior to the end of 1983, all city bank shares traded in the same narrow range of around 500 yen, shown for Sumitomo Bank. The post-1983 rise in the share price of Sumitomo Bank was also experienced by other city banks, although their share prices stopped moving in lock-step. The surge in bank share prices was followed by large primary stock offerings by the city banks at the higher market prices. Viner (1988) reports that the proceeds of the share offerings were earmarked to finance computer facilities and overseas acquisitions. ${ }^{9}$

\section{International}

The Foreign Exchange Law of 1980 marked a watershed in Japanese financial policy; it reversed the presumption that all international financial transactions by Japanese residents w'ere subject to control unless explicitly recognized. In particular, it ushered in a period in which the overseas operations of Japanese commercial banks became no longer overwhelmingly dedicated to implementing trade finance strategies to support the growing share of world trade accounted for by Japan's exports of finished goods and imports of raw

9. See Viner, Aron. Inside Japanese Financial Markets, Dow Jones-Irwin, Homewood Illinois, 1988, pp. 214-216. 
materials. That is, through the passage of the 1980 law, Japanese authorities recognized the need for flexibility in the overseas activities of Japanese banks, which then enabled the banks to begin to respond to the increasingly sophisticated financing requirements of their internationally active corporate customers. In this light, two measures contained in the Foreign Exchange Law proved to be of particular importance in integrating Japanese domestic money markets with international markets. They were the authorizations for Japanese banks to borrow and lend foreign currencies freely (both at home and abroad), subject only to prudential guidelines, and for Japanese companies to finance themselves abroad through foreign currency-denominated borrowing.

Throughout the early 1980s, the Japanese authorities further reformed their regulation of Japanese residents' participation in international markets. The cumulative effect of these reforms was the opening up of important channels of intermediation through which Japanese interest rate conventions could be readily circumvented by transactions routed via offshore financial markets. Chart 6 shows the substantially tightened linkage of domestic and Euroyen interest rates from 1980 onward. The standard deviation of the differential between Euroyen rates and domestic gensaki rates was reduced by 88 percent between the 1975-1980 period and the 1981-1985 period. It was also true that reforms such as the 1984 abolition of "swap limits" for spot transactions had the effect of repatriating yen money markets from abroad as evidenced by the post-1984 surge in the volume of transactions booked in those markets that we discussed above. ${ }^{10}$

10. See Osugi, K. Japan's Experience of Financial Deregulation since 1984 in an International Perspective, BIS Economic Papers No. 26, Bank for International Settlements, Basle, January 1990. 
Throughout the late 1980s, the Euroyen market expanded sharply. In particular, there was a strong surge in cross-border yen lending to the Japanese nonbank sector primarily by the offshore offices of Japanese banks, a form of bank lending that was not covered by the Bank of Japan's window guidance of individual banks' loan growth. Japanese commentary suggests that accommodation of such borrowing was a component of a strategy for domestic financial reform in which foreign experience was to be used to inform the implementation of domestic financial reform. This interpretation is bolstered by Osugi's commentary on the role of cross-border lending in reducing the importance of window guidance by the Bank of Japan for restraining competition among Japanese banks. 11

\section{Section III. Elements of Japanese Financial Liberalization}

\section{Interest Rate Reform}

The gensaki market, along with the chokuku (the government bond mutual fund) market, $^{12}$ engendered a disintermediation of funds from the banking sector, as corporations rapidly sought to capture the significantly higher yields in markets offering unregulated interest rates. The consequent funding pressure on the Japanese banks caused by disintermediation led to the introduction of negotiable certificates of deposit offered by commercial banks at liberalized interest rates. At the outset, the restrictions set for $C D$ issuance narrowly limited the maturity, minimum denomination, and amount of the CDs authorized by the Japanese government. These restrictions have gradually been eased as the

11. Osugi (1990), op. cit., p. 68.

12. The chokuku market was developed by the securities companies in 1980; a chokuku fund is essentially a money market mutual fund that invests its assets in medium-term Japanese government bonds. 
process of interest rate liberalization has continued. A chronology of the liberalization of Japanese deposit interest rates is shown in chart 7.

The succession of regulatory reforms that followed the introduction of unregulated rate CDs in 1979 has caused the interest costs of banks to become increasingly sensitive to movements in market interest rates. Of special importance to this change was the 1985 introduction of money market certificates (MMCs), which yield interest rates based on the CD rate, with specific formulas according to denomination. Chart 8 depicts the steady increase in the percentage of Japanese bank deposits that offer liberalized rates; the steady increases have been accounted for by relaxations of minimum denomination and maturity restrictions.

In addition, Chart 8 displays the negative effects on profitability of the heightened reliance of Japanese banks on market-rate based sources funds in the late 1980s-a time of rising short-term interest rates. In response to their increased interest sensitivity, the banks altered their method of prime rate determination for both short and long-term loans (in 1989 and 1991, respectively), so that the new rates are formulated based on the banks' actual cost of funds. While this innovation has the potential to help stabilize bank interest margins in a market-rate based funding environment, the banks encountered strong resistance from customers with alternative financing sources during the period of rising interest rates in 1989 and 1990 (see Chart 9). Overall, as discussed below, the attempt by the banks to raise the profitability of their corporate lending activities has produced important changes in the compositions of banks' corporate loan customers. 
A method by which Japanese banks have historically raised effective yields above nominal loan rates involves the use of compensating balance requirements. Chart 10 shows the percentage of loan contracts under which small corporate borrowers are required to hold interest-free (or low interest) deposits either as part of the official loan contract, or in order to maintain a "healthy, stable relationship" with the lender. ${ }^{13}$ The reliance on compensating balances declined steadily throughout the 1980 s from 45 percent of surveyed loan contracts in 1980 to 26 percent in 1990 . However, in view of the rising share of banks' small corporate loan customers, the overall reduction in lending under such arrangements as a percentage of banks' corporate loans may be considerably smaller.

Chart 11 presents the distribution of loan contracts in 1990 that required compensating balances, broken down by the size of the required balances as a percent of the respective loans. The average compensating balance rate in 1990 was around 20 percent (although recall that less than 30 percent of surveyed loan contracts require any compensating balances at all). Chart 12 shows the differential between average short-term loan rates and $\mathrm{CD}$ rates, and adjusts for the impact of compensating balance requirements in order to determine the effective lending spreads throughout the period. The chart displays the higher profitability to banks of lending to corporate customers with the use of compensating balance arrangements.

One problem now facing the banks is that compensating balance arrangements inflate the asset base by increasing the book value of the loan portfolio to a level above that of

13. The data on compensating balances were taken from an annual survey by the Japan Fair Trade Commission. The survey only includes companies with less than 100 million yen in capital. Companies of this size now encompass approximately 70 percent of total city bank lending. Only a small share of loan contracts with compensating balances involves legally binding (contractual) arrangements between the borrower and the lender. 
the funds actually extended. This asset inflation has led to the dilemma now faced by Japanese banks over whether to induce further shifts by loan customers away from the now profitable balance arrangements, or to maintain the arrangements at the cost of an overly intensive use of bank capital during a period in which capital allocation has by necessity become a primary factor in Japanese bank operations management. In addition, the need for the banks to meet international bank capital adequacy standards (discussed in section IV) exacerbates the problems caused by the continuing use of balance requirements.

In addition to the effects of the overall rise in Japanese interest rates, the banks recently have been faced with a downward sloping yield curve. Downward sloping yield curves have negative consequences for ordinary banks in Japan (which include the city and regional banks), since these banks are constrained under Japanese regulations from issuing most forms of long-term liabilities, yet have increasingly extended long-term loans. Restrictions on the maturity of assets and liabilities were put into place as part of the separation between short-term and long-term providers of credit in the 1940s and 1950s. Despite the short-term nature of their liabilities, the city banks have been steadily extending the maturity of their total loan portfolio: the percentage of loans with terms of greater than 1 year original maturity has grown from 33 percent in 1980 to 53 percent in 1990. The lengthening of original maturity of Japanese bank lending, over time, has been significantly influenced by the strong increase in corporate liquidity in Japan (see chart 13) and the development and growth of short-term financing vehicles, such as commercial paper. Thus, the maturity lengthening reflects a shift away from working capital financing to project-based lending (including real estate lending). Furthermore, it follows that some of the recent deterioration in corporate liquidity ratios among the large surveyed firms 
might be associated with their resistance to the introduction of new loan pricing standards, particularly the long-term prime lending rate.

The process of interest rate deregulation in Japan has forced a rationalization of the banking business in terms of raising and lending funds. As the importance of the administratively-determined interest rate structure fades, banks will face an increasingly competitive environment for the first time in the post-war era. It is important to note that the fallout from the increase in bank competition will be staggered throughout the period of gradual elimination of interest rate restrictions. As displayed earlier in Chart 5 , the Japanese city banks have remained ahead of the smaller regional and cooperative bank sectors in terms of their share of deposits paying liberalized interest rates. Yet, as the minimum denomination of money market-related deposit instruments continues to decline while deregulation proceeds, the impact upon the smaller institutions (whose predominantly small business clients will then be able to access the instruments) will be further realized.

Only at this point will the full implications of complete interest rate liberalization become evident.

\section{Corporate Financing Developments}

Historically, Japanese city banks had close relationships with the largest Japanese companies. Over time, the largest companies have become less dependent on banks for their financing needs, a byproduct of various developments including the introduction of alternative sources of corporate finance. In response, the city banks have placed much greater emphasis in recent years on developing relationships with small and medium-sized businesses, which previously had been heavily financed by interfirm trade credit extensions from the largest Japanese companies. In fact, over the period 1986-1990, the share of bank 
loans to large Japanese corporations declined by nearly 20 percentage points to 30 percent (see Chart 14).

Chart 15 compares the overall sources of finance for Japanese corporations over two periods, 1981-1985 and 1986-1990. In the earlier period, trade credit accounted for 18 percent of corporate finance as compared with only 5 percent in the second period. The shift in bank relationships, referred to above, reconciles the seemingly small decline in overall bank financing of 7 percentage points with the reduced share of trade credit as a percent of corporate finance. The increased importance of domestic and international securities markets as sources of funds for large Japanese companies is reflected in the nearly 30 percent share of corporate funds raised in 1986-1990 period through the issuance of domestic securities (including commercial paper) and borrowings in international markets. Borrowings in international markets included large amounts of equity-related bonds by Japanese banks and companies, in the forms of both convertible bonds and straight bonds with detachable warrants. 14

Chart 16 depicts the substantial increase in funds raised through the issuance of bonds by Japanese private non-bank corporations in the international market through 1990. Japanese corporations have favored this form of direct financing over domestic bank

14. Japanese corporations (inclusive of banks) issued more than $\$ 30$ billion of Swiss franc convertible bonds from 1987 on. According to market observers, few issuers hedged the currency exposure of those issues in view their strongly held view that the securities would inevitably be converted to stock. Japanese corporations believed that convertible issues offered lower costs of equity issuance than direct issuance of equity, perhaps reflecting the Japanese practice of offering new issues at a discount from market price to existing share holders. The choice of denominating a convertible issue in a foreign currency, such as the Swiss franc, was strongly influenced by the fact that the lower nominal cost of such issue would result in higher reported current earnings than if the issue was denominated in yen. There is little evidence that the "speculative" nature of such financing choices by various Japanese firms, prior to sharp 1990 drop in the Japanese stock market, was factored into market assessments. 
financing due to the significant cost advantages found through the issuance of debt. One of the reasons for the cost differential between debt and bank loans has stemmed from the Japanese regulation that prohibits city banks from accessing nearly all forms of long-term funding (see city bank limitations in Chart 2). This restriction has induced the banks to alter their method of long-term prime rate determination from one based on long-term market rates to one based on pre-set spreads above the short-term prime rates in order to have lending rates float at fixed spreads over cost of funds. ${ }^{15}$

However, the new loan pricing scheme generates high bank lending rates relative to market interest rates during periods in which the Japanese yen yield curve is inverted. Chart 17 exhibits one recent manifestation of this situation by comparing the Japanese bank prime rate structure to the Euroyen yield curve as of April 1991. ${ }^{16}$ The gap between the rates charged for prime loans by the city banks and those available in the Euromarket provided an incentive for internationally-recognized high quality borrowers to search actively for less costly alternatives to bank funding. ${ }^{17}$ The inverted yield curve placed the barks in a dilemma between lending competitively at rates which would generate little

15. The Japanese banks are rapidly increasing their use of swap transactions as a means of hedging against this type of interest rate risk. Swap trading on the Tokyo market is estimated to have increased by 360 percent in the year to September 1991 (to $\$ 24.1$ billion).

16. Note that the two interest rate structures are not entirely comparable since interest costs on loans based on the prime rate can include one or more rate reset options, while Euroyen rates are of a fixed interest rate for the indicated maturity. In fact, it is our understanding that an increasing proportion of city banks' long-term loans have been at variable interest rates.

17. "Overseas Markets Beckon," International Financing Review, issue 875 (April 27, 1991), and "IADB Readies First Floating-Rate Note," International Financing Review, issue 877 (May 11. 1991). The two articles identify the dichotomy between corporate lending rates and the Japanese longterm prime rate and describe how this led recently to the first floating-rate bond issued in Japan. 
return on assets, and forgoing the financing of corporations in which they continue to maintain equity interests through cross-shareholdings.

Section IV. Implications of the Basle Capital Accord

\section{Background}

In the early 1980s, central banks and regulatory authorities became increasingly sensitive to the absence of mutually agreed-upon rules for conduct in the international banking business. The international debt crisis raised additional concerns regarding the fragility of the international banking system, in view of the potential consequences of debtor country actions on the financial situations of a large number of internationally active banks. This led national authorities in the United States and other industrial countries to begin to press banks to bolster their capital adequacy positions.

In the second half of the 1980s, the international assets of Japanese banks surged dramatically. The Japanese bank share of international bank assets rose by more than 10 percentage points to 38 percent from 1984 to $1988 .^{18}$ This surge raised questions as to whether national banking regulators could successfully induce banks to improve their capital ratios in the absence of barriers being raised against further market penetration by Japanese banks. In turn, the possibility of such protectionist responses intensified efforts to move to a level playing field for internationally active banks through the adoption of international capital standards.

18. The reported share is based on data on international banking assets reported to the Bank for International Settlements. The data are reported to the BIS by the G-10 and other reporting countries. The data include claims of banking offices on non-local customers in foreign and domestic currencies and claims on local residents in foreign currencies. 
The task was assigned to the Basle Committee on Banking Supervision, a grouping of G-10 member countries' central banks and bank regulators. ${ }^{19}$ By the end of 1987, the Committee had agreed on a framework which called for a common capital definition and a riskasset weighting scheme rather than a leverage ratio. The simplicity of the negotiated framework facilitates comparisons among banking systems. In particular, unlike pre-existing national capital definitions with multiple tiers of capital, the new framework has only two (Tier I and Tier II capital). Tier I capital consists of only the core constituents of the capital base, namely, equity and disclosed reserves. Tier II capital includes supplementary elements, such as subordinated debt and revaluation reserves. While the specific composition of Tier II was left to national discretion, the Committee specified several binding limitations on the inclusion of instruments in Tier II, including a 45 percent limit on unrealized gains on securities holdings and a limit on includeable subordinated debt at a level of 50) percent of Tier 1 capital.

The Basle Committee also agreed on a timetable which established transitional target capital ratios during the implementation period. Internationally active banks are required to meet an 8 percent minimum standard by the end of 1992, of which at least half must constitute Tier I capital. It was widely appreciated that the Basle framework was far from perfect in the sense of establishing truly equivalent minimum capital standards for internationally active banks. In particular, the framework did not allow for the effects of various national accounting standards and tax policies.

The Basle framework is a negotiated document in which the situations of individual banking systems are mirrored. For example, the inclusion of subordinated debt in Tier II

19. The secretariat of the Basle Committee is furnished by the BIS. 
capital had (at the time of negotiation in the 1980s) no operational significance for Japanese city banks. The banks were not permitted to issue subordinated debt at the time the agreement was negotiated. ${ }^{20}$ This was not the case for U.S. money center banks which had relatively large amounts of such debt outstanding as a result of previous efforts to improve their U.S. regulatory capital ratios (in which credit is given for subordinated debt). On the other hand, Japanese city banks possessed substantial revaluation reserves, reflecting unrealized gains on their cross-shareholdings in other Japanese companies. This was not the case for U.S. banks.

It was widely expected that the requirements in the capital agreement would induce Japanese banks to slow the growth of their balance sheets. One perspective on the agreement suggests that Japanese banking authorities viewed their situation as equivalent to that of Japanese trade negotiators who were pressured to accept orderly marketing agreements as a cost of maintaining continued access for Japanese goods to specific foreign markets. In this view, the Basle agreement was a means of negotiating restrictions on the growth of Japanese banks' shares of various national banking markets. A separate line of reasoning argues that Japanese authorities actually sought the agreement as a means of leveraging their own efforts to encourage the financial reform process in Japan. While the two explanations are not mutually exclusive, we find the latter explanation more supportable when viewed from an historical perspective, in the sense that important structural reforms in Japan have historically been portrayed publicly to be the undertaking of a sacrifice that

20. However, as discussed later in the paper, in 1990 Japanese banking regulators authorized to issue subordinated debt as Tier II capital. 
had be undertaken in order to placate hostile foreigners. 21

The expectations of the framers of the Basle agreements were not fulfilled in the sense that the asset growth of Japanese banks was not immediately restrained. In particular, the severe fluctuations in the Japanese stock market in the late 1980s had important consequences for the financial situations of Japanese banks.

\section{The Capital Raising Activities of Japanese Banks}

The purpose of this section is to analyze the response of Japanese banks to the Basle Capital Accord. The capital raising efforts of the Japanese banks following the adoption of the new capital framework was phenomenal; from 1986 to 1990, the Tier I capital of the Japanese city banks has increased at an average annual rate of 21 percent. Chart 18 shows the strong positive correlation of the Tier I capital positions of the city banks with the upward movement of the Japanese stock prices in the late 1980s. The correlation is largely accounted for by Japanese banks capitalizing on opportunities presented by the favorable terms available for the issuance of new equity and equity-based securities (convertible bonds denominated in yen and other currencies) as well as the realization of gains on their stock holdings. ${ }^{22}$ Chart 18 also shows the sharp fall in the Japanese stock market in 1990 and 1991; this decline not only made it more difficult for Japanese banks to

21. Students of the Japanese system continue to debate the role of Admiral Perry's "black ships" in prompting the structural reforms undertaken by the Meiji state.

22. In the late 1980s, Japanese authorities effectively discouraged Japanese banks from reducing their exposures to heavily indebted middle income countries through secondary market sales at a discount. However, the banks were permitted to reduce their exposures in connection with their participation in restructuring agreements for Argentina, Brazil and Mexico; and, subsequently, in connection with their involvement in so-called Brady-debt reduction agreement for Mexico. The resulting tax losses from such transactions were offset were by the capital gains from stock sales that were routinely reversed so as to permit the bank to meet its obligations to be a reliable shareholder of client firms. 
issue new equity securities (including through conversions of outstanding convertible bonds by investors), but also adversely affected the attractiveness of boosting Tier I capital through the realizations of latent gains on stock holdings. This point is discussed in detail below.

The top panel of Chart 19 relates the growth of a proxy of Japanese city banks' aggregate Tier I capital to their growth of assets. The bottom panel of Chart 19 shows that the resulting capital-asset ratio declined slowly in the period 1981-1986, and increased sharply from 1987 onward. ${ }^{23}$ The strong capital growth since 1987 has enabled nearly all Japanese banks to reach the 8 percent risk-adjusted capital/asset ratio stipulated in the Basle agreement.

While the banks have been successful in bolstering their capital positions since 1987, the fall in Japanese stock prices weakened sharply the capacity of the banks to support further asset growth at the banks' historical rates. Chart 20 documents the capital positions of the city banks before and after the 1990 stock market decline. Prior to 1990 (the left side of the chart) the banks were constrained by the Basle Accord limits on the amount of allowable Tier II capital (represented by the distance AB). ${ }^{24}$ While in this constrained position, any additions to Tier I capital through retained earnings or equity issues also raised the ceiling on Tier II capital by an equal amount (segment BC);

23. Japanese accounting practices require banks to value securities at the lower of cost or market. This accounting convention meant that the stock market decline had little direct impact on banks' reported Tier 1 positions since most stocks continued to be reported on the basis of cost of acquisition.

24. Under the final Basle Accord guidelines, Tier II capital may only be included in total bank capital up to the level of existing Tier I capital (i.e., Tier II must constitute 50 percent or less of the total). 
therefore, every additional unit of retained earnings (including realization of gains on sales of equity) pulled in another unit of surplus unrealized gains (for a total of two new units of capital) to fund asset expansion.

As a result of the stock market decline in 1990 (the right side of the chart), however, the drop in unrealized capital gains has caused Tier II capital to fall below the BIS ceiling of 100 percent of Tier I capital. Under this regime, increases in capital through retained earnings or equity financing (from $A B$ to $A C$ ) now fund only half as much asset expansion (since there is no longer any surplus Tier II capital). Additions to banks' risk-based asset totals now face much higher effective capital charges compared with to the situation that prevailed prior to the drop in the stock market. 25

The two panels of Chart 21 depict the capital gains that the banks realized from the sale of equity securities, and the level of equity financing over the period 1985-1990. From the charts, it is clear that the banks were sharply affected by the weakness in the Japanese stock market in 1990; for example, the city banks issued approximately $¥ 18$ trillion in common stock in 1989, but refrained from new stock issuance in 1990. In response to the erosion of the banks' capital bases caused by the stock market decline, Japanese authorities

25. The capital ratios of the city banks are also sensitive to exchange rate movements. It is our estimated rule of thumb that a 10 yen change in the yen-dollar exchange rate will result in a .1 percentage point change in the aggregate Basle risk-weighted ratio of the Japanese city banks. This reflects Japanese supervisory rules that operate to immunize a bank's total capital and not its capital ratio from exchange rate movements. Nevertheless, the limited movement of the yendollar exchange rate in recent years have meant that exchange rate changes has not been an important influence on city banks' capital ratios. 
permitted the banks to issue subordinated debt (to be counted as Tier II capital). ${ }^{26}$ While this innovation alleviated some of the negative impact of the stock market on the capital positions of the banks, the financial consequences of the replacement in bank capital of "costless" unrealized gains on shareholdings by costly subordinated debt were reflected by reductions in the returns on city banks' assets by 5 basis points to 17 basis points and in returns on their equity by 168 basis points to 6.65 percent in fiscal year 1990. City bank profits were also negatively affected by the mounting expenses associated with the ongoing support of affiliated nonbank financial institutions that are among the major creditors of so-called bubble companies. 27

\section{Capital Adequacy and Bank Asset Growth}

The aggregate worldwide assets of the Japanese city banks declined by 3.3 percent in fiscal 1990 (measured in yen)--the first asset decline since prior to World War II. This decline in assets was more than accounted for by a reduction in interbank placements and deposits. Overall loan growth remained positive. At the U.S. banking offices of Japanese city banks, business loan growth was significantly stronger than for U.S. banks in fiscal 1990. This outcome was, in part, attributable to the earlier efforts of city banks to increase their market share of U.S. business lending through the provision of various

26. More than 3.7 trillion yen (approximately $\$ 27$ billion, or about 30 percent of the city banks' aggregate Tier 2 capital at the start of fiscal 1990) of subordinated debt was issued in fiscal 1990.

27. The bubble companies are those firms which have been heavily involved in speculative investments, mainly in real estate. The ongoing financial difficulties of these firms have not been reflected by the city banks through increased provisions for loan losses. This reflects Japanese accounting rules that do not provide for the disclosure of probable loan losses. Thus, over the next few years, the earnings of the city banks will continue to be adversely affected by losses on loans to bubble firms in financial distress. 
committed backup facilities, including those provided to firms that normally financed themselves in the U.S. commercial paper market. In fiscal 1991, Japanese banks have not had strong loan growth, a retrenchment consistent with their efforts to adjust to less-favorable financial circumstances.

Overall, available data and anecdotal evidence suggest that the following has been the typical response of the Japanese city banks to binding capital requirements. First, the city banks cut back on the allocation of capital to support money-market activities. Second, the banks raised pricing objectives for domestic and international credits in order to guarantee sufficient returns of equity and assets. Third, the banks have begun to sell off their stock holdings in Japanese firms with whom they do not expect to have sufficiently profitable long-term relationships (as measured by profitability indicators such as return on assets or return on equity).

Chart 22 shows the relationship between city banks' asset growth and capital needs for different levels of the Nikkei stock index. The difference between the two lines is accounted for by the fact that at a Nikkei index value of 39,000 there would be a Tier II surplus, whereas, at a Nikkei index value of 26,000 there is a Tier II shortfall. Thus, for example, we estimate that the city banks would have to add $\$ 30$ billion in capital at the current value of the Nikkei of about 24,000 to support a 10 percent annual increase in their assets (rather than only $\$ 15$ billion if the Nikkei were at its peak level of 39,000 ). The difference between the necessary additions to the capital base is indicative of the heightened financial costs which would have faced the city banks if they had not chosen to restraint the growth of their assets. 


\section{Section V. The Outlook for Further Financial Reform in Japan}

The segmentation currently present in the Japanese financial system is much greater than that in the United States or any other industrialized economy. The Japanese system of specialized banking and credit intermediaries has remained largely unchanged since its original configuration following World War II. Traditional Japanese decision-making has operated to create a reform process in which the impact of various liberalization measures must be deftly balanced between all constituencies, thereby demanding that every attempt be made to minimize the costs inflicted upon any one sector of the financial system. Such insurance or loss-sharing arrangements have operated to preserve a segmented system by necessitating a gradualized approach to deregulation in which adequate time must be given in order to accurately assess the impact of each new liberalization measure before undergoing additional measures (recall the 15-year process of interest rate deregulation shown in Chart 7).

Within this framework, regulatory barriers to entry have been claimed as the property rights of the protected firms. The negotiation of compensation for the removal of various restrictions on intersectoral competition has added significantly to the difficulties of reforming the Japanese financial structure. ${ }^{28}$ For example, it is now probable that Japanese government financial reform proposals will not call for the provision

28. Horne has examined how Japanese financial regulatory policy is formulated and implemented. Through case studies, he illustrates a set of relevant idiosyncrasies which stem from the Japanese institutional and political framework. Nevertheless, he admonishes the reader to be prepared to recognize "...that there is much in the process of regulatory policy-making in Japan's financial markets which policymakers and participants in other countries will recognize." [Horne, James. Japan's Financial Markets: Conflict and Consensus in Policymaking George Allen \& Unwin, Sydney, 1985]. 
of stock brokerage services by Japanese banks. ${ }^{29}$ It is our understanding that this decision has been strongly influenced by concerns about the adverse consequences of bank entry on the competitive positions of the smaller securities firms. We have listed in Chart 23 a number of the specific elements that are contained in the Japanese government's financial reform proposals. It is important to note that Japanese financial companies presently operating in various sectors would be allowed to enter into new financial activities only through separate special-purpose subsidiaries. In the Japanese proposals, the emphasis is on the maintenance of separability among all of the various financial service activities. By constrast, the focus of the U.S. Treasury's 1990 proposal from financial system reform was on assuring the separability of banking activities from other activities of a financial services firm, a separation motivated by the view that the coverage of the various elements of the U.S. federal government safety net should be restrained.

In the past, Japanese banks have been encouraged to compete for regulatory privileges. In the 1980s, such competition among Japanese financial institutions appears to have been channeled to international markets by regulatory actions designed to accommodate and encourage the internationalization of Japanese finance. In the late 1980s, the character of such competition appears to have been influenced by the strong increase in financial wealth controlled by the banks in the forms of unrealized capital gains on the stock holdings. In our view there have been important spillover effects from such competition among Japanese banks that have been observed in the outcomes in various

29. This is not an issue in the present U.S. discussion of financial reform. Under the current U.S. regulatory regime, U.S. banks are permitted to control firms that provide stock brokerage services. 
financial markets, for example, encouragement of the specialization by U.S. banks in the processes of credit origination and financial engineering. 30

In summary, the change-over to capital-based regulation of Japanese banks should, in itself, encourage important changes in the structure of domestic and international banking markets. If the Japanese stock market proves to be less buoyant over the next few years, the capacity of the Japanese banks to implement change in a deliberate and considered fashion will be reduced. It is likely that there will be important spillover effects from this process, including those associated with changes in the role of Japanese banks as financial monitors of Japanese nonfinancial firms. ${ }^{31}$

30. For additional information on recent developments in financial structure reform in Japan, see Tetsuya Morimoto and William J. Seiter, "Japan's financial system reform: stalled on the tracks," International Financial Law Review, (September 1991), pp. 30-33.

31. For a more extended discussion of the possible significance of differences in national financial structures see Frankel, Allen B. and John D. Montgomery. "Financial Structure: An International Perspective," Brookings Papers on Economic Activity 1991, pp. 257-310. 


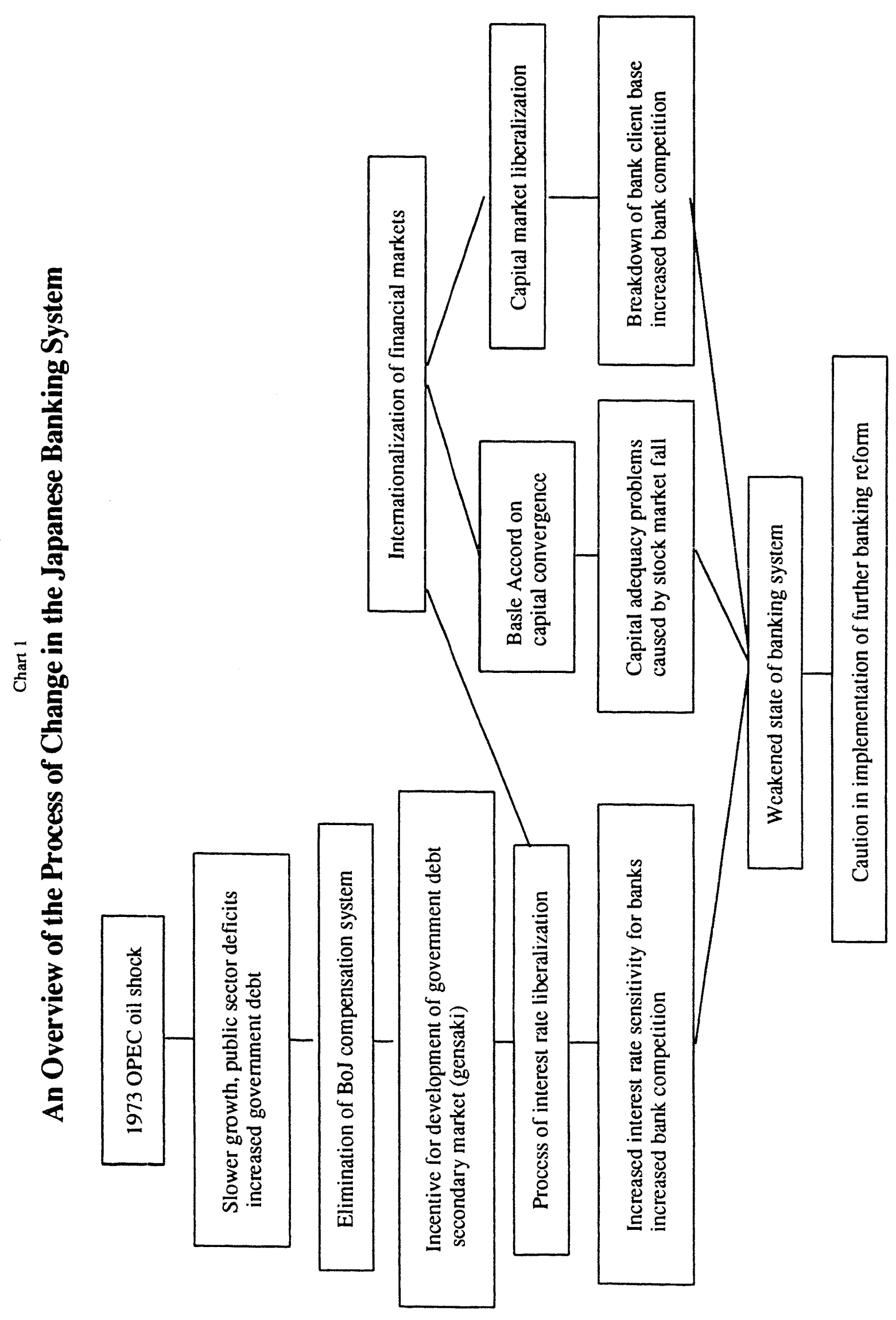




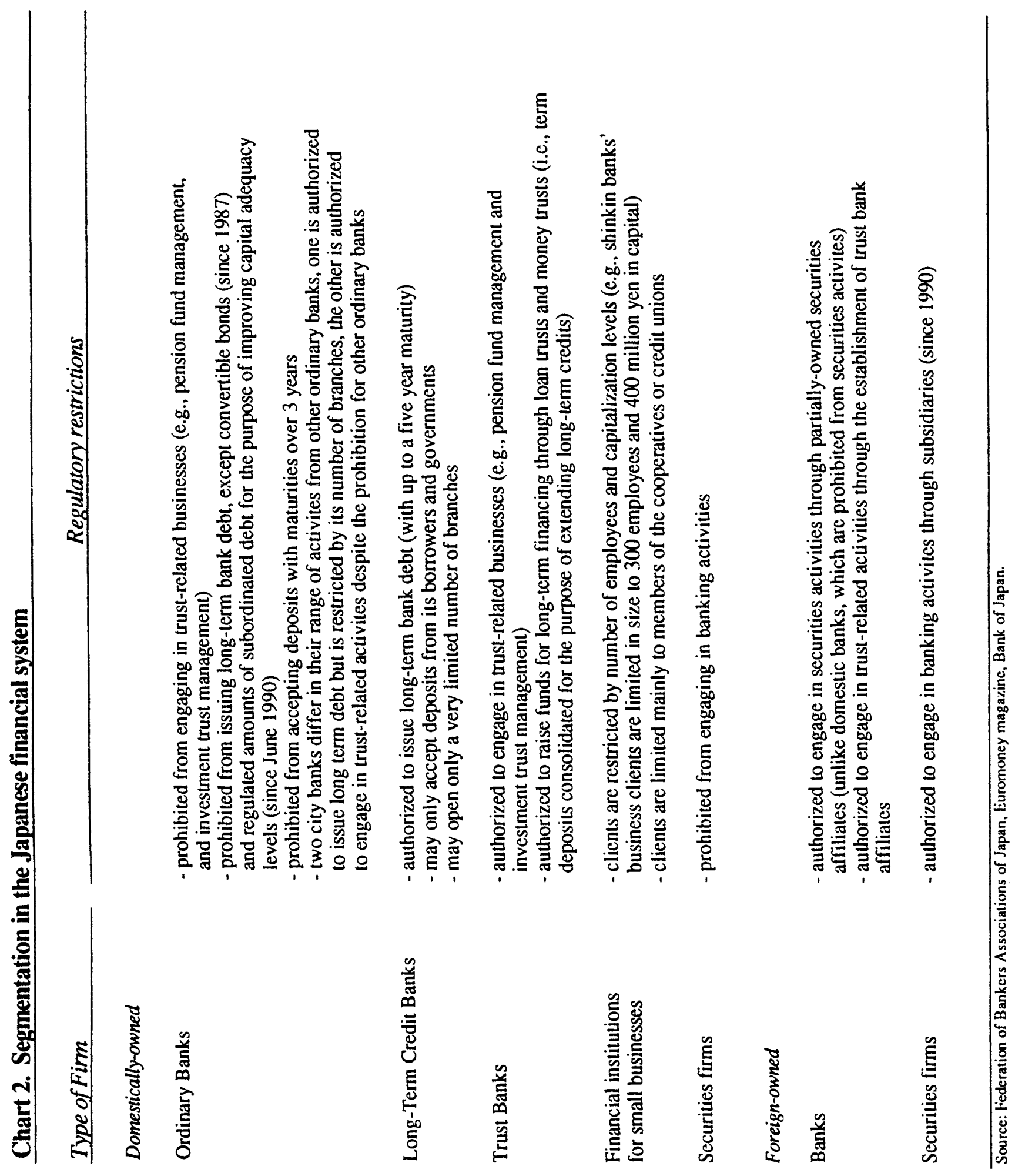




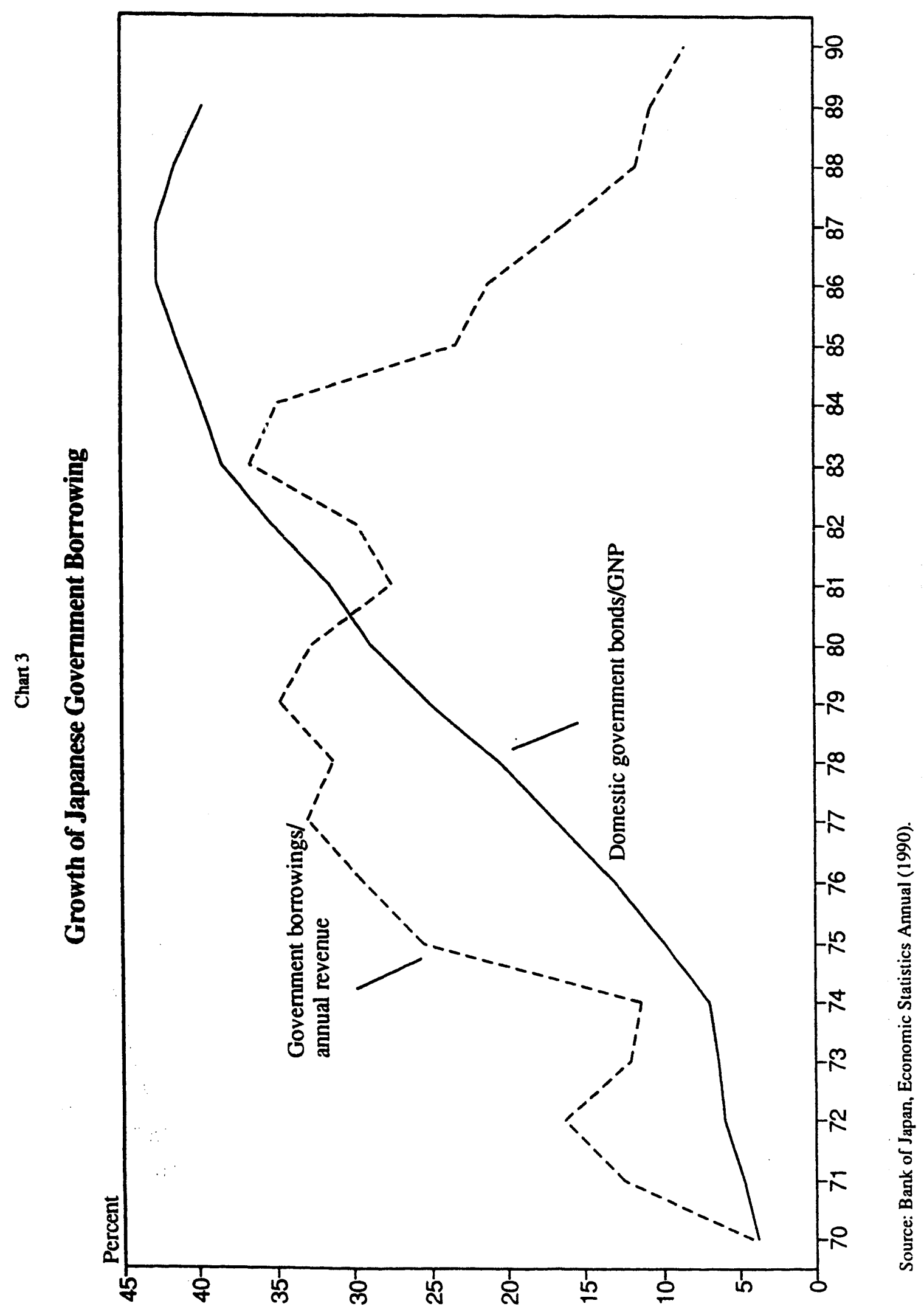




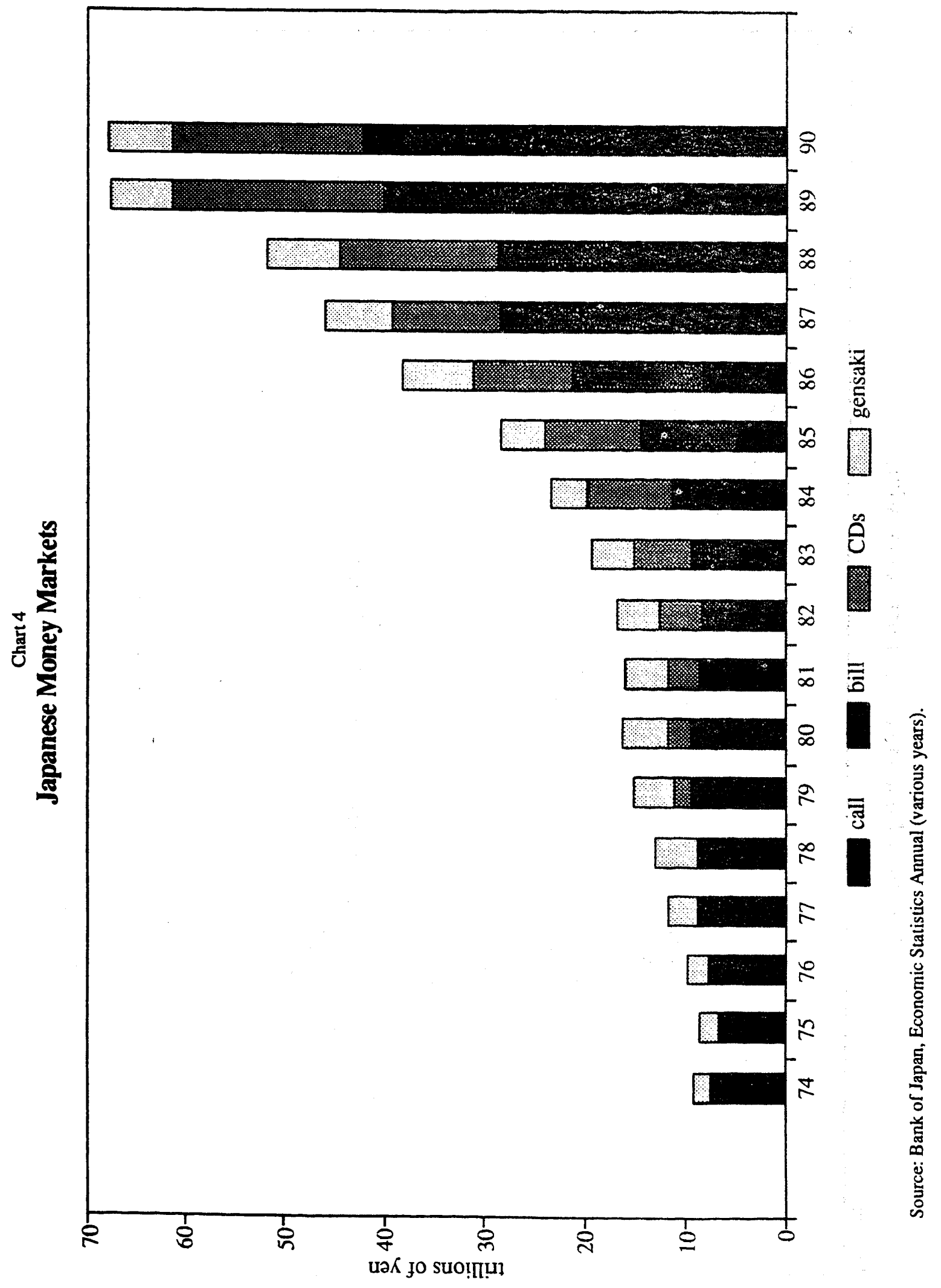




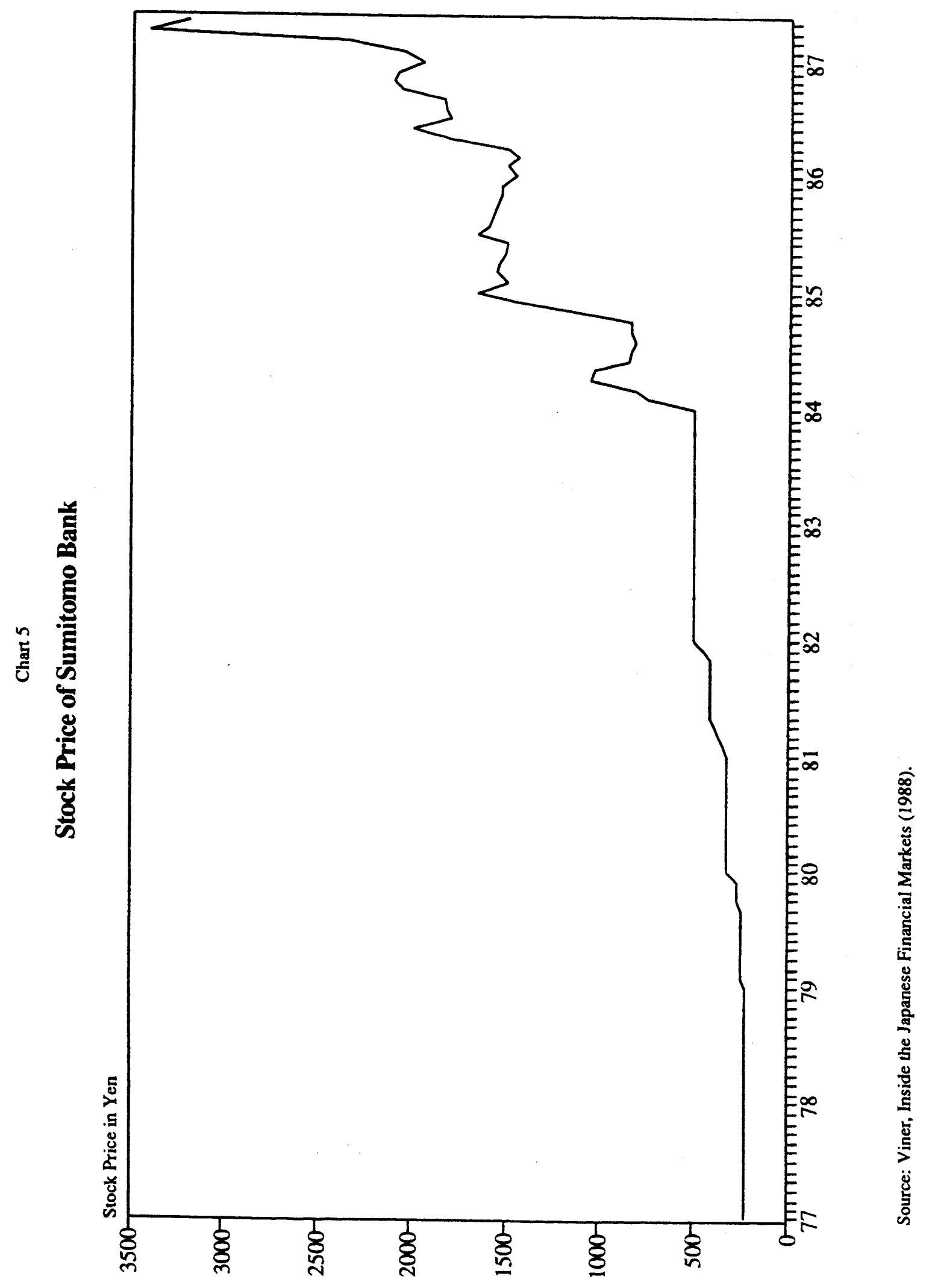




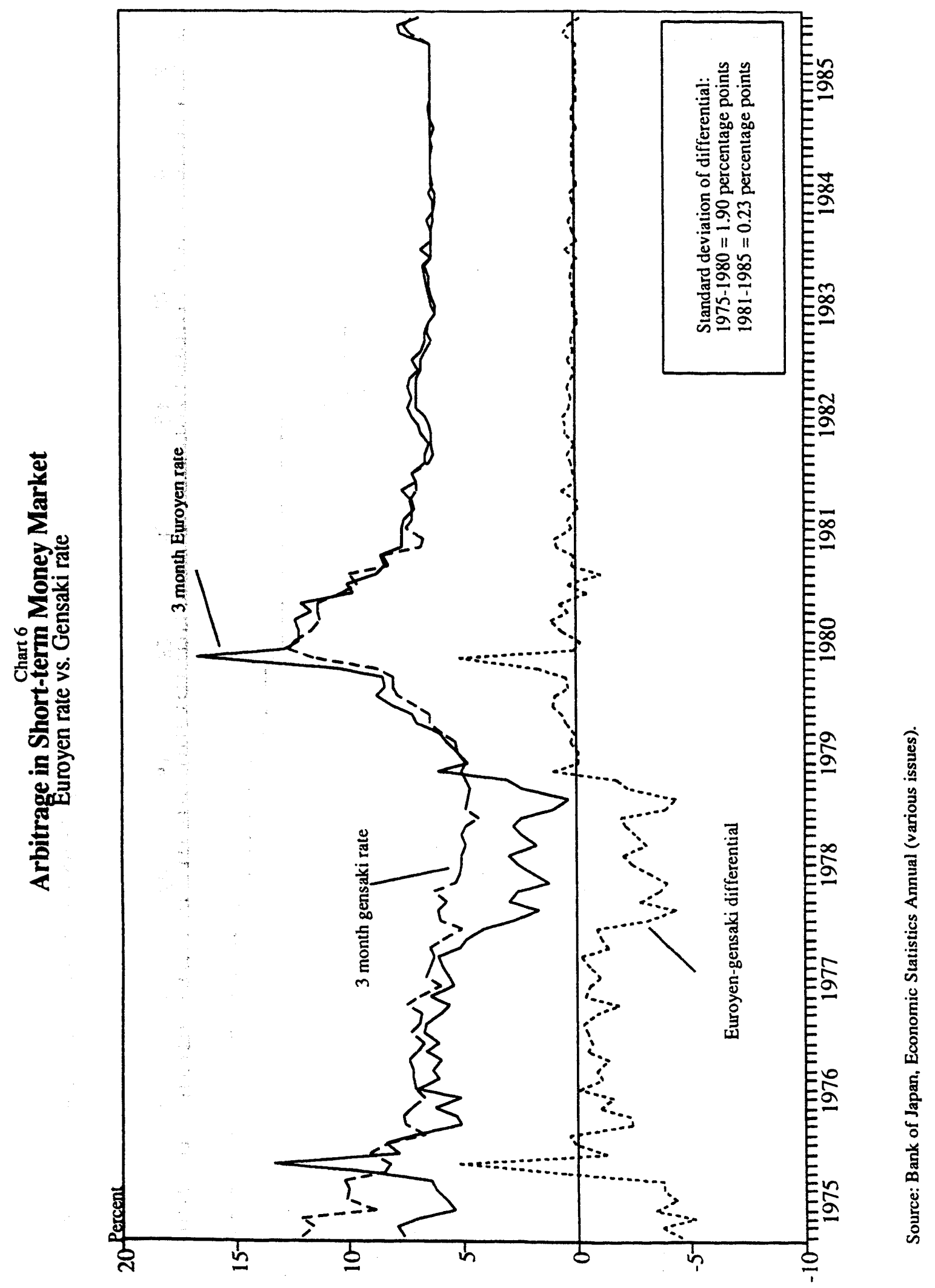




\section{Chart 7}

\section{History of Deregulation of Deposit Interest Rates}

1979 May - Issuance of Negotiable Certificates of Deposit authorized (minimum amount $=¥ 500$ million, term $=3$ to 6 months)

1984 Jan - Minimum denomination of CD lowered to $¥ 300$ million

1985 Apr - Minimum denomination of CD lowered to $¥ 100$ million, minimum term shortened to 1 month - Issuance of Money Market Certificates authorized (minimum amount $=¥ 50$ million, term $=1$ to 6 months)

Oct - Deregulation of interest payable on large time deposits (minimum amount $=¥ 1$ billion, term $=3$ months to 2 years)

$1986 \mathrm{Apr}$ - Maximum term of CD extended to 1 year

- Minimum denomination of large time deposits lowered to $¥ 500$ million

- Maximum term of MMC extented to I year

Sep - Minimum denomination of large time deposits lowered to $¥ 300$ million

- Minimum denomination of MMCs lowered to $¥ 30$ million

1987 Apr - Minimum denomination of large time deposits lowered to $¥ 100$ million

- Minimum denomination of MMCs lowered to $¥ 20$ million

- Maximum term of MMC extended to 2 years

Oct - Minimum term of large time deposit shortened to 1 month

- Minimum denomination of MMCs lowered to $¥ 10$ million

1988 Apr - Minimum denomination of CD lowered to $¥ 50$ million, term broadened to 2 weeks to 2 years

- Minimum denomination of large time deposits lowered to $¥ 50$ million

Nov - Minimum denomination of large time deposits lowered to $¥ 30$ million

1989 Apr - Minimum denomination of large time deposits lowered to $¥ 20$ million

Jun - Small denomination MMCs introduced (minimum amount $=¥ 3$ million, term $=6$ months to 1 year)

Oct - Minimum denomination of large time deposits lowered to $¥ 10$ million

- Term of small MMCs broadened to 3 months to 3 years

1990 Apr - Minimum denomination of small MMCs lowered to $¥ 1$ million

1991 Apr - Minimum denomination of small MMCs lowered to $¥ 500$ thousand

Timetable for future interest rate deregulation

1991 Nov - Minimum denomination of large time deposits lowered to $¥ 3$ million

1992 Jun - Minimum denomination of small MMCs eliminated

- Introduction of "non-time" deposit instruments bearing market-related interets rates (minimum denomination $=¥ 200$ thousand)

1993 - All remaining controls on time deposit rates to be fully removed

1994 - Remaining restrictions on all "non-time" deposit rates will be removed (exccpl "current" deposits)

Note: For reference, as of October 10,1991 , the yen/dollar exchange rate was $130 ¥ / \$$ (e.g., $¥ 1$ million $=\$ 7,690)$.

Sources: Federation of Bankers Associations of Japan and unpublished reports by the U.S. Treasury Financial Altache in Tokyo. 


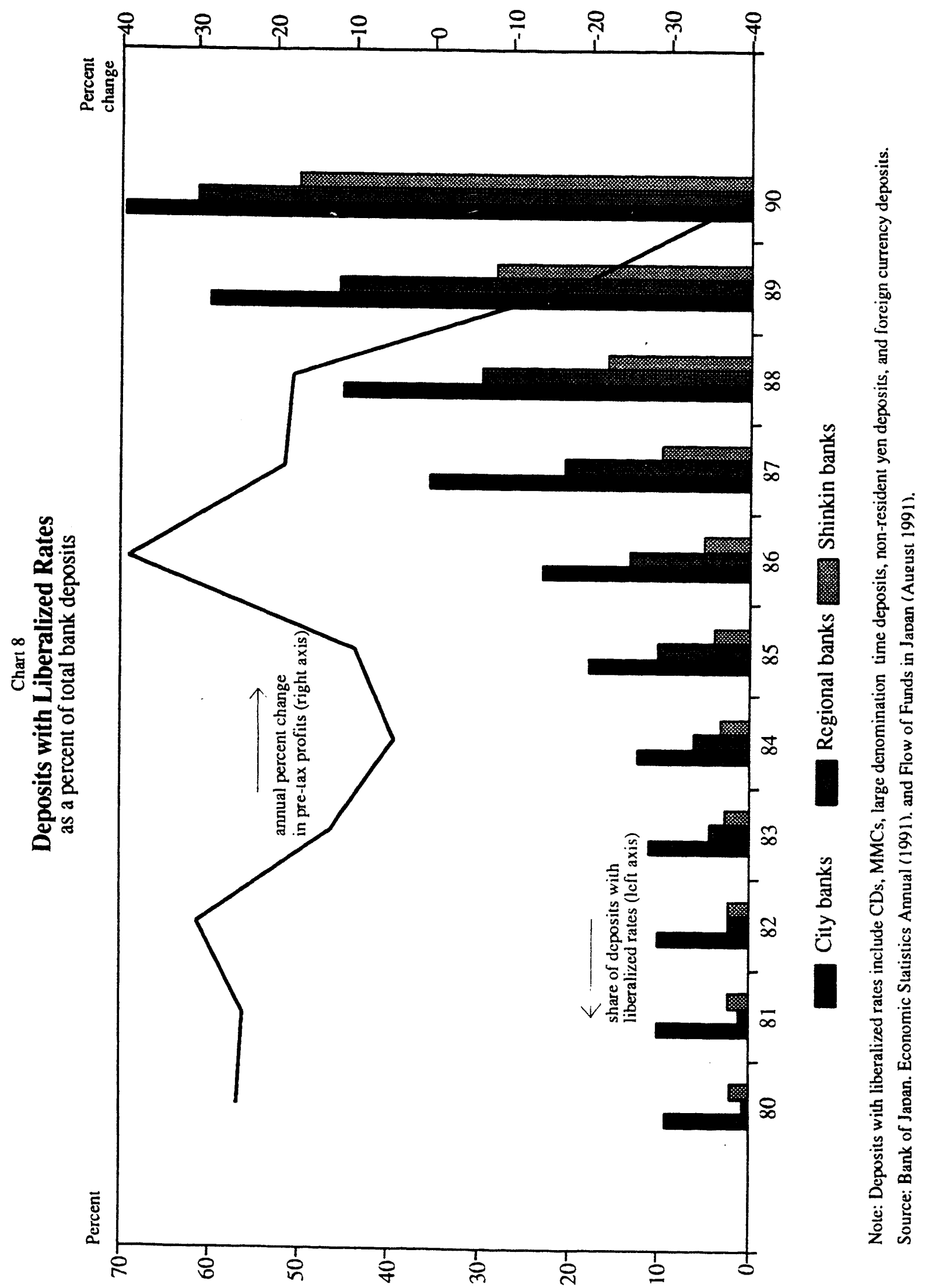




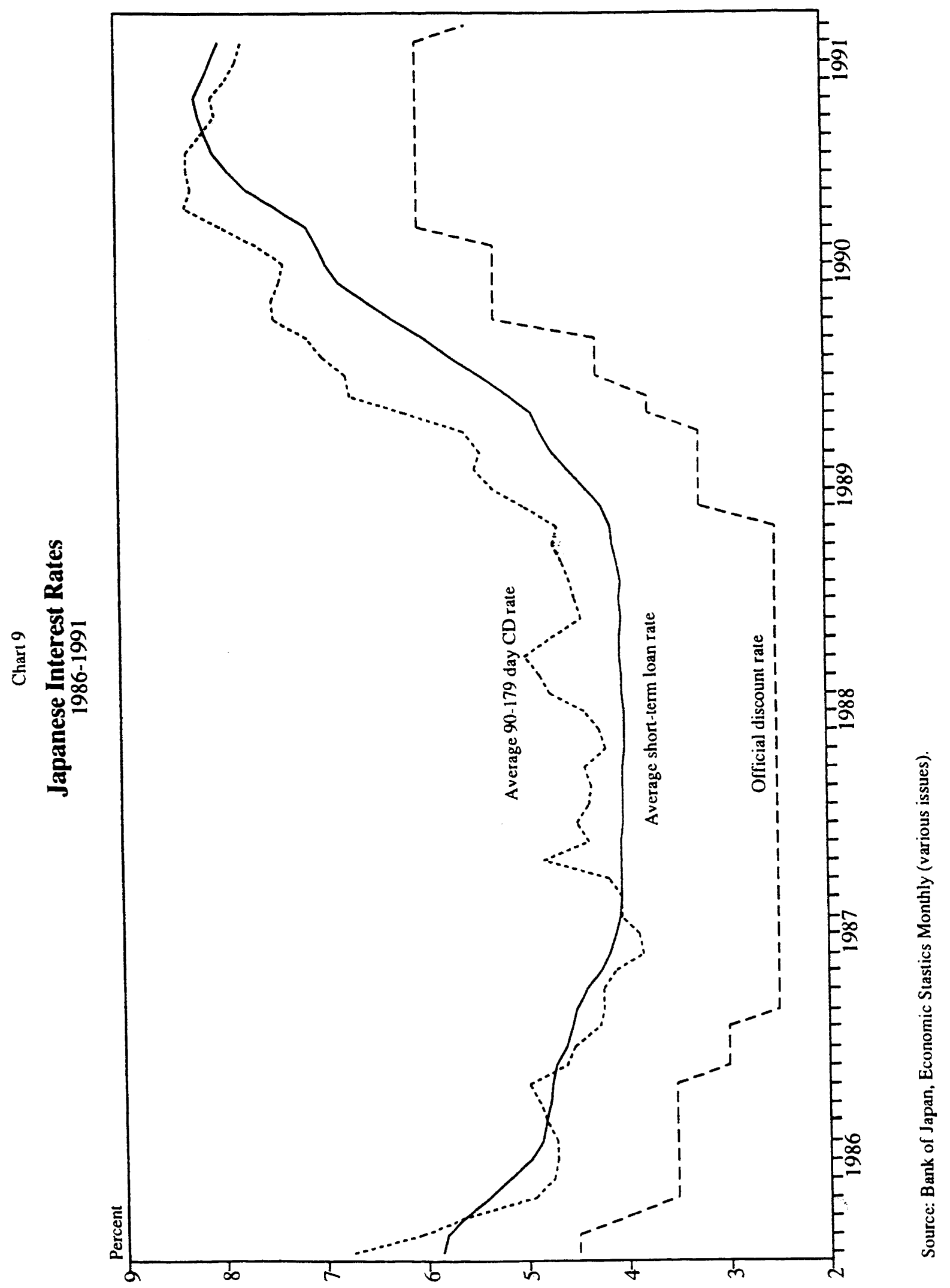




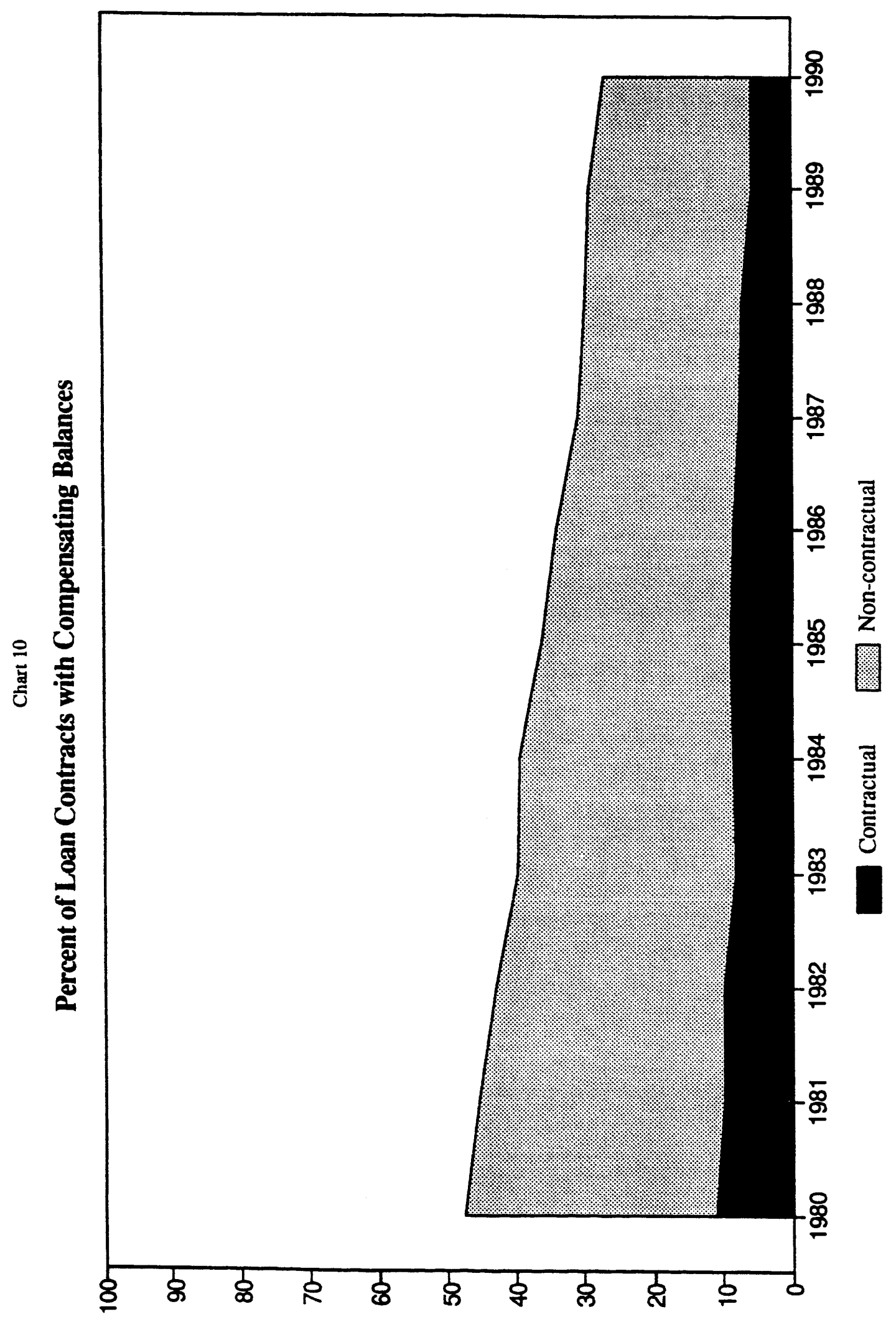

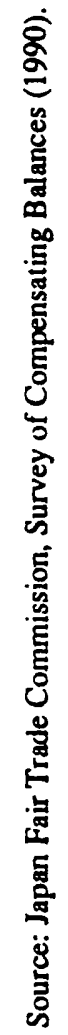




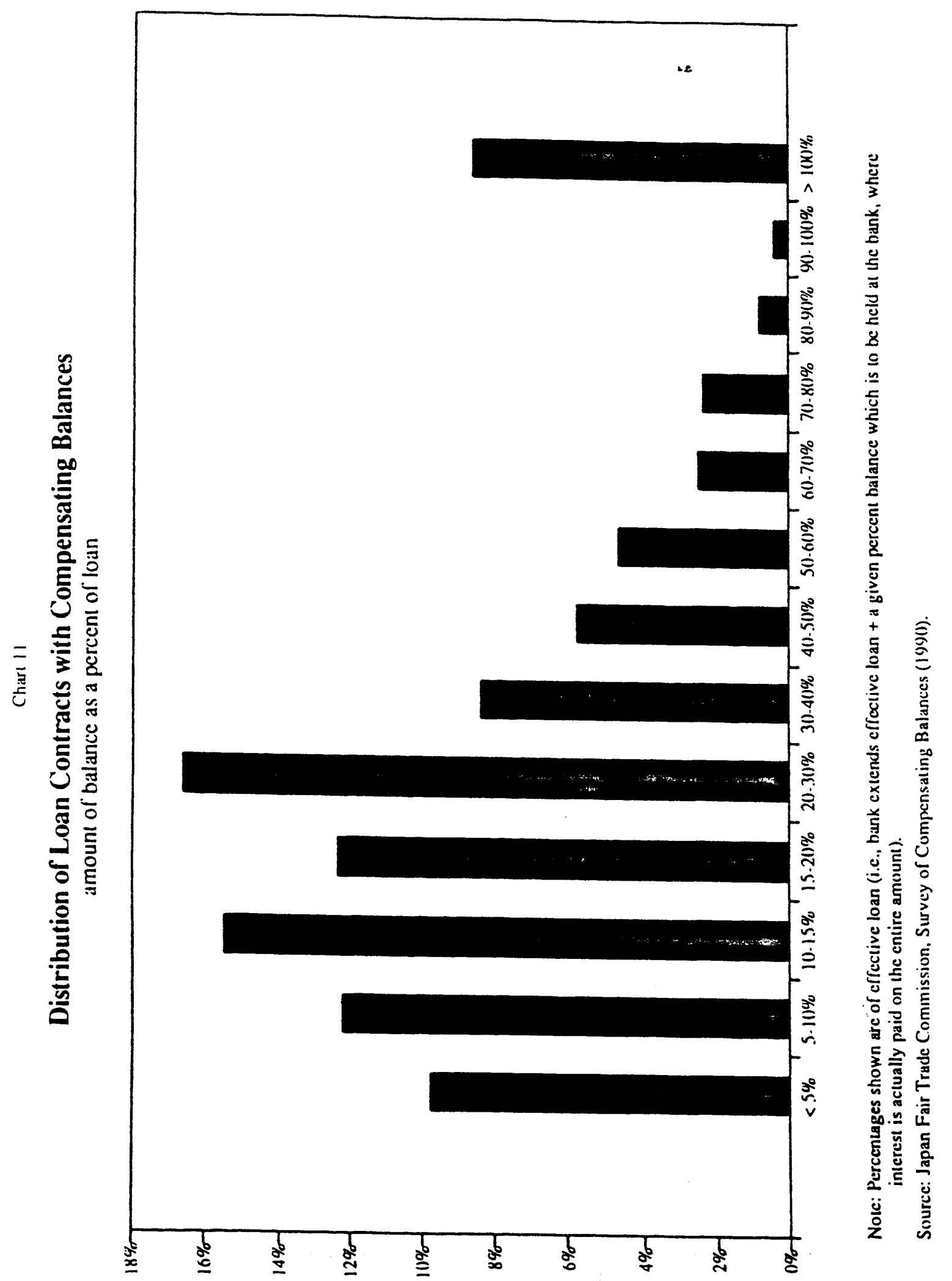




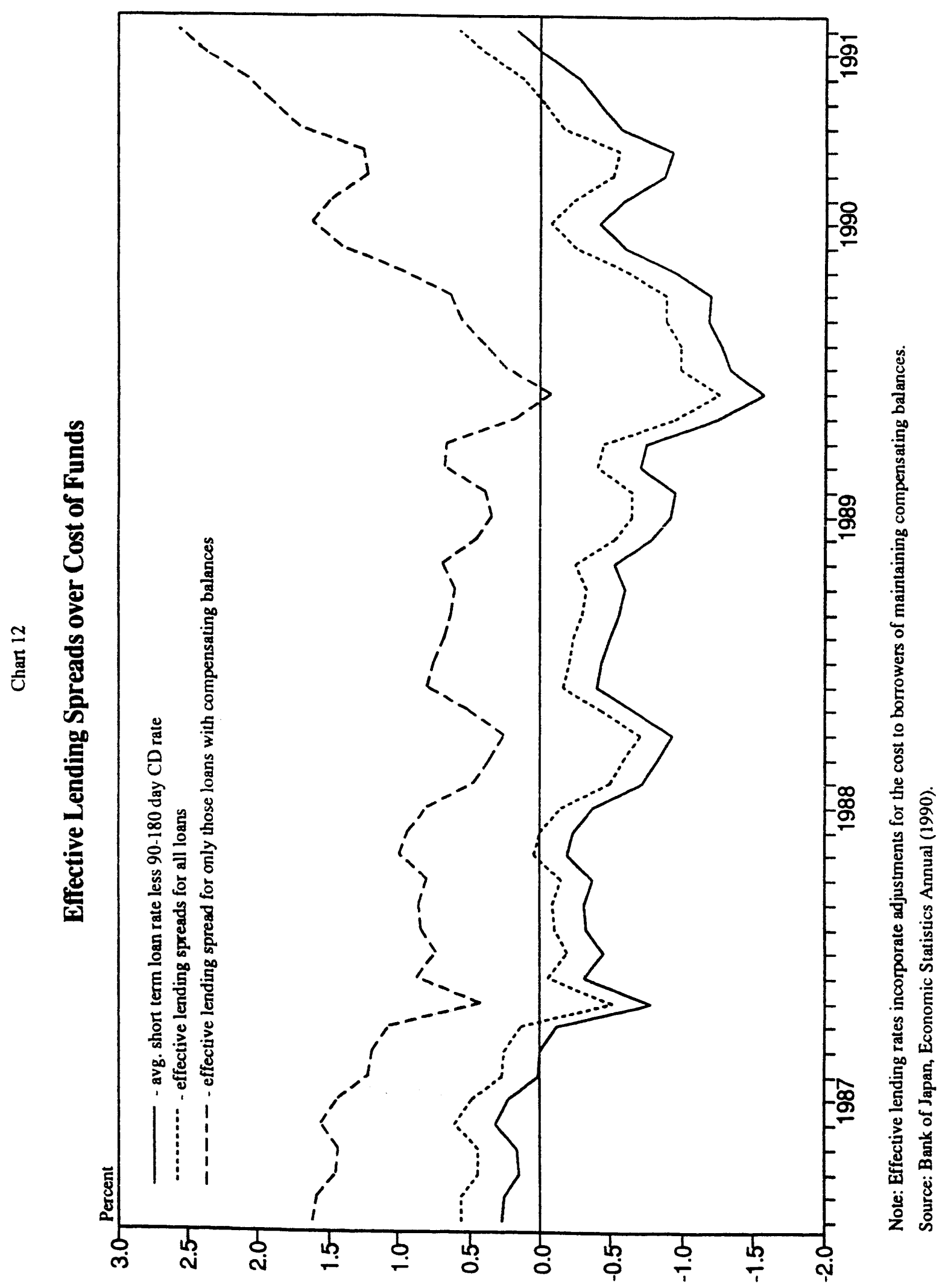


- $39-$

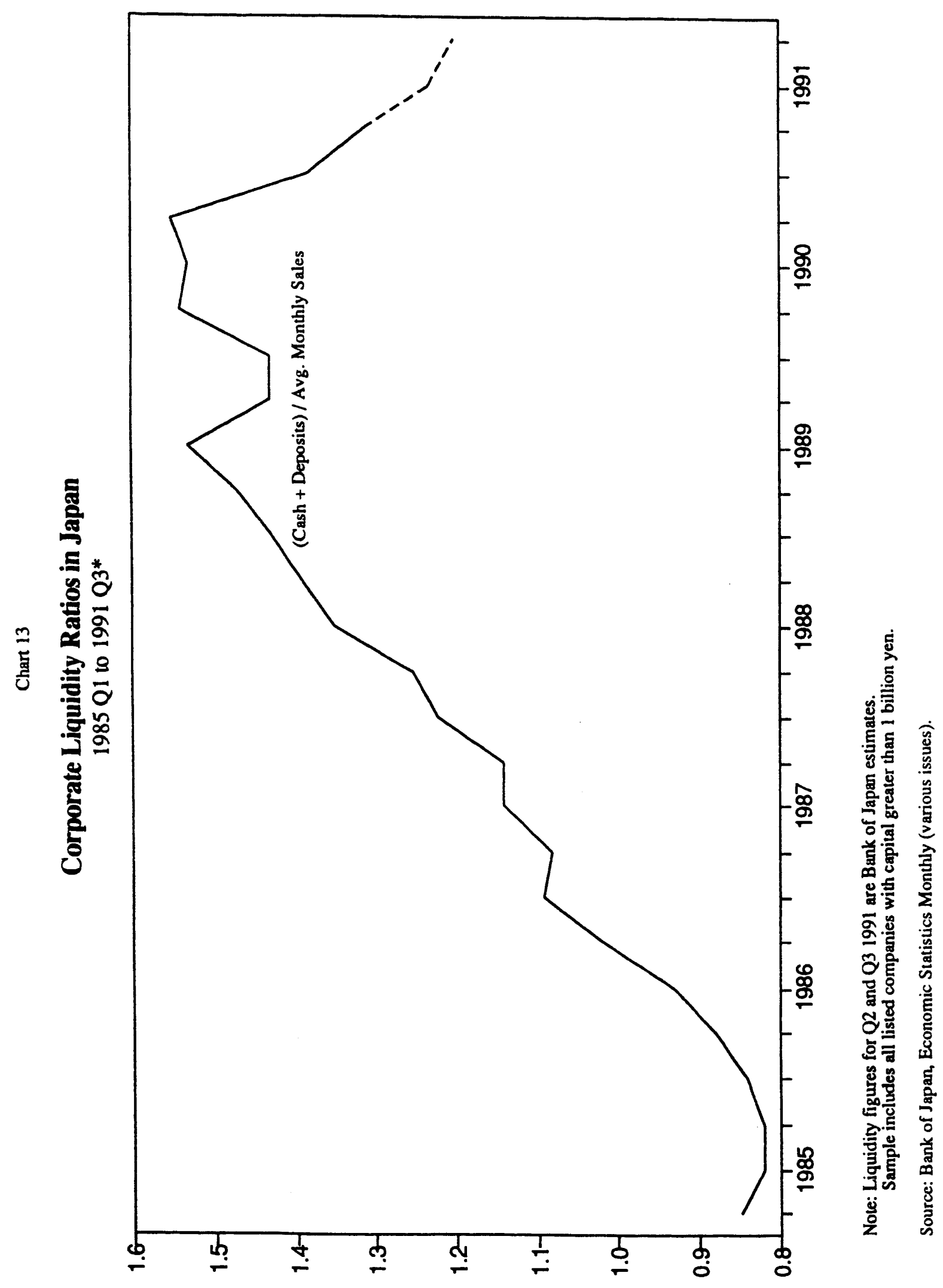




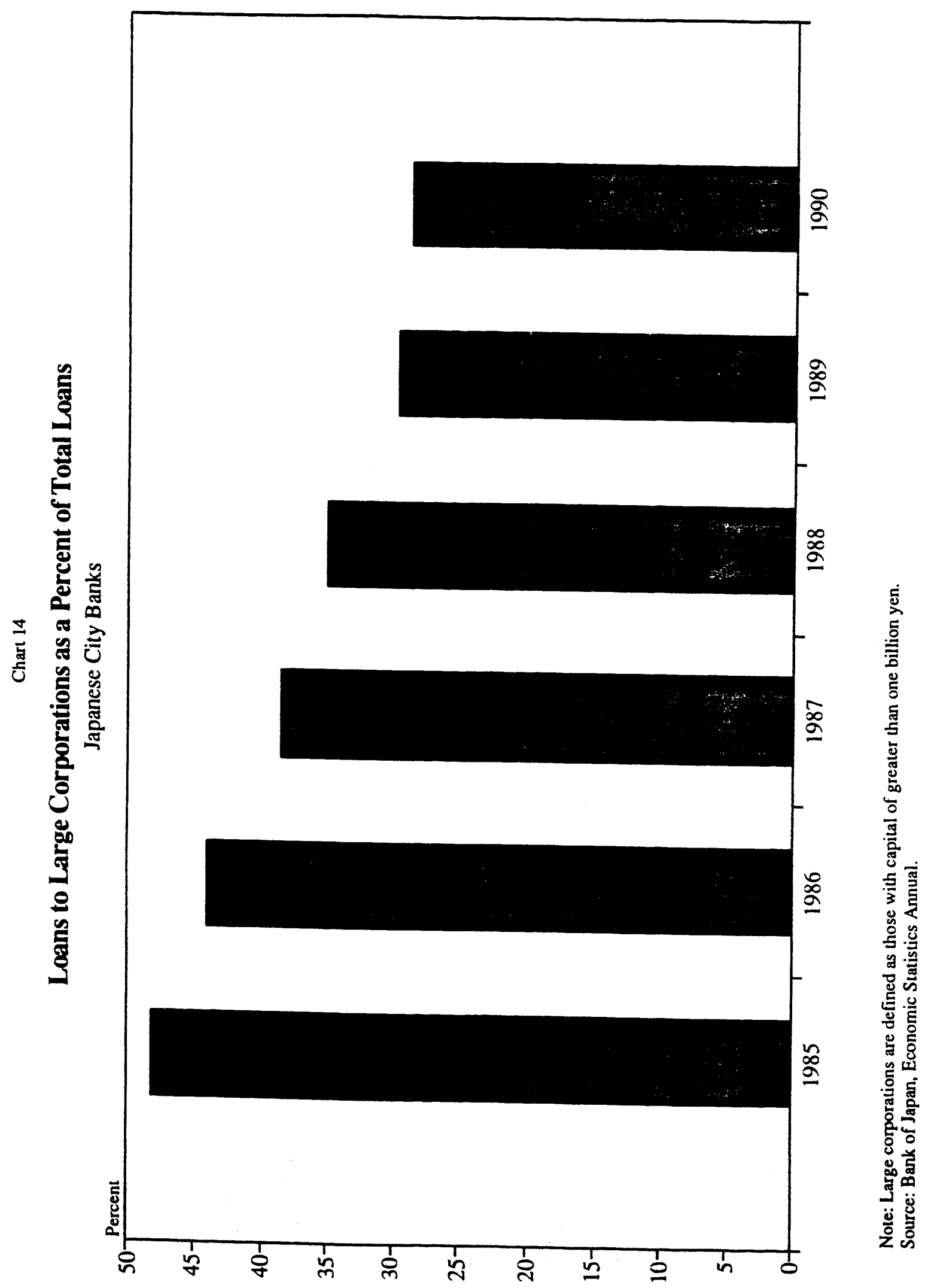




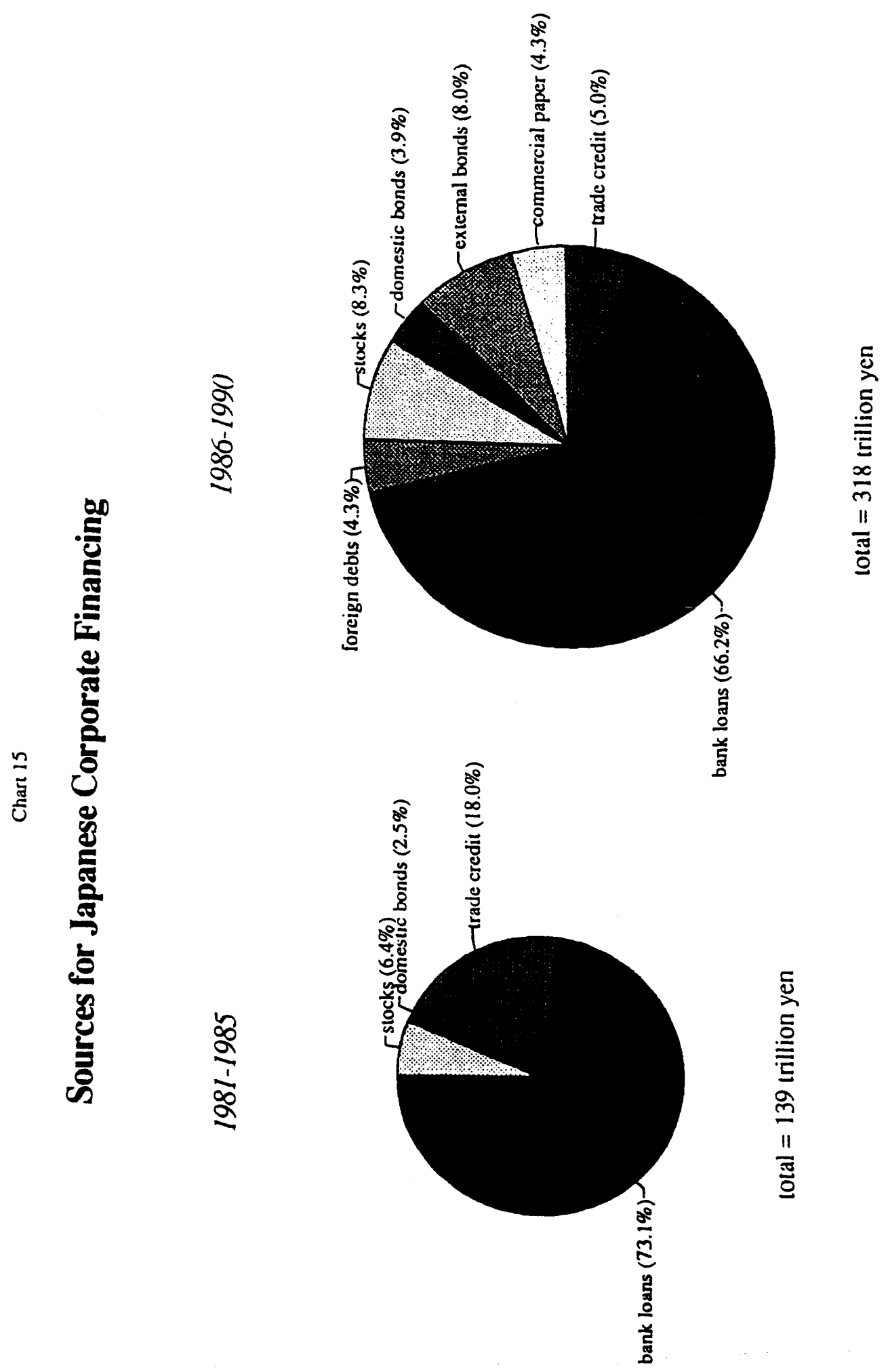




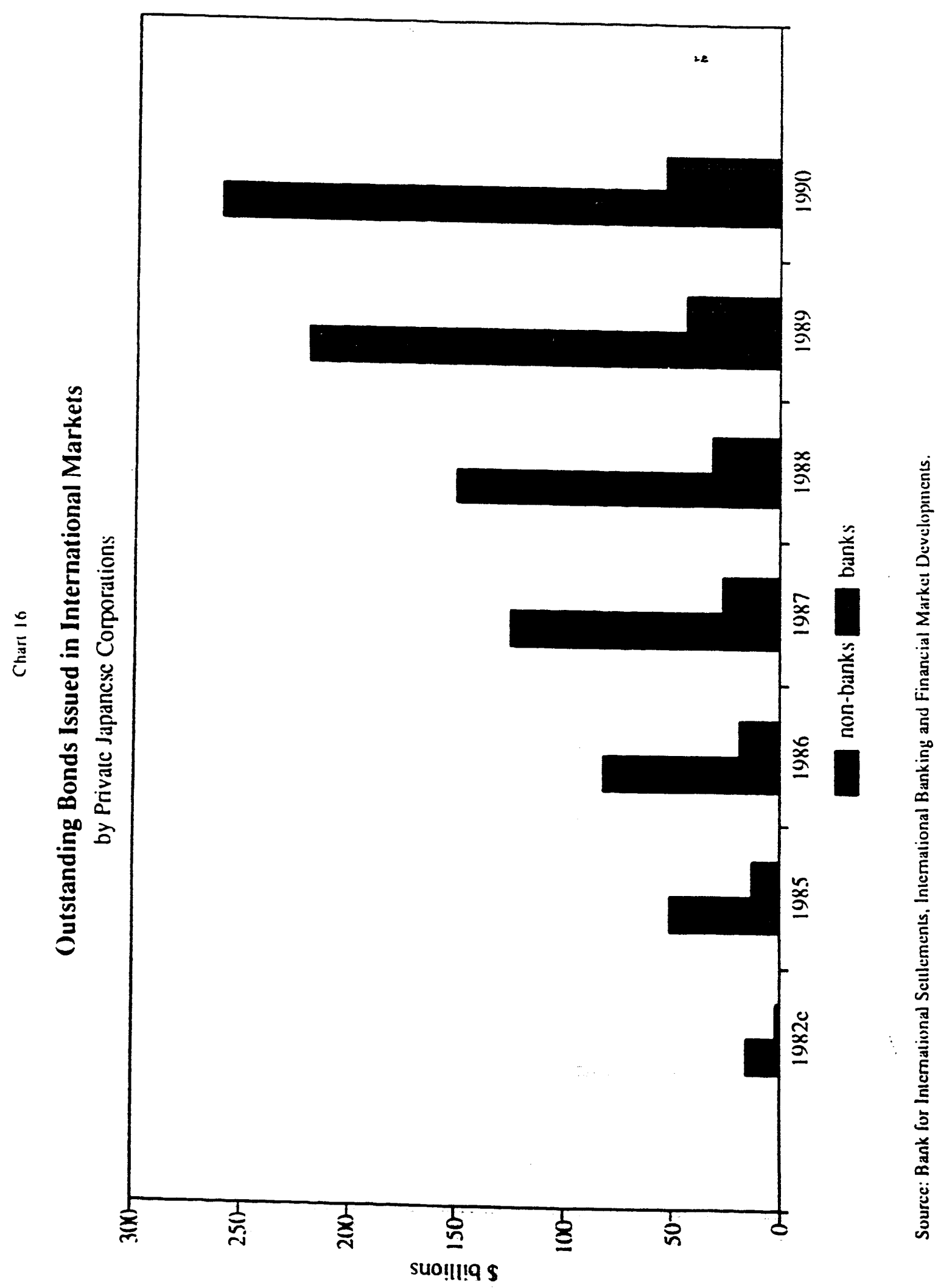




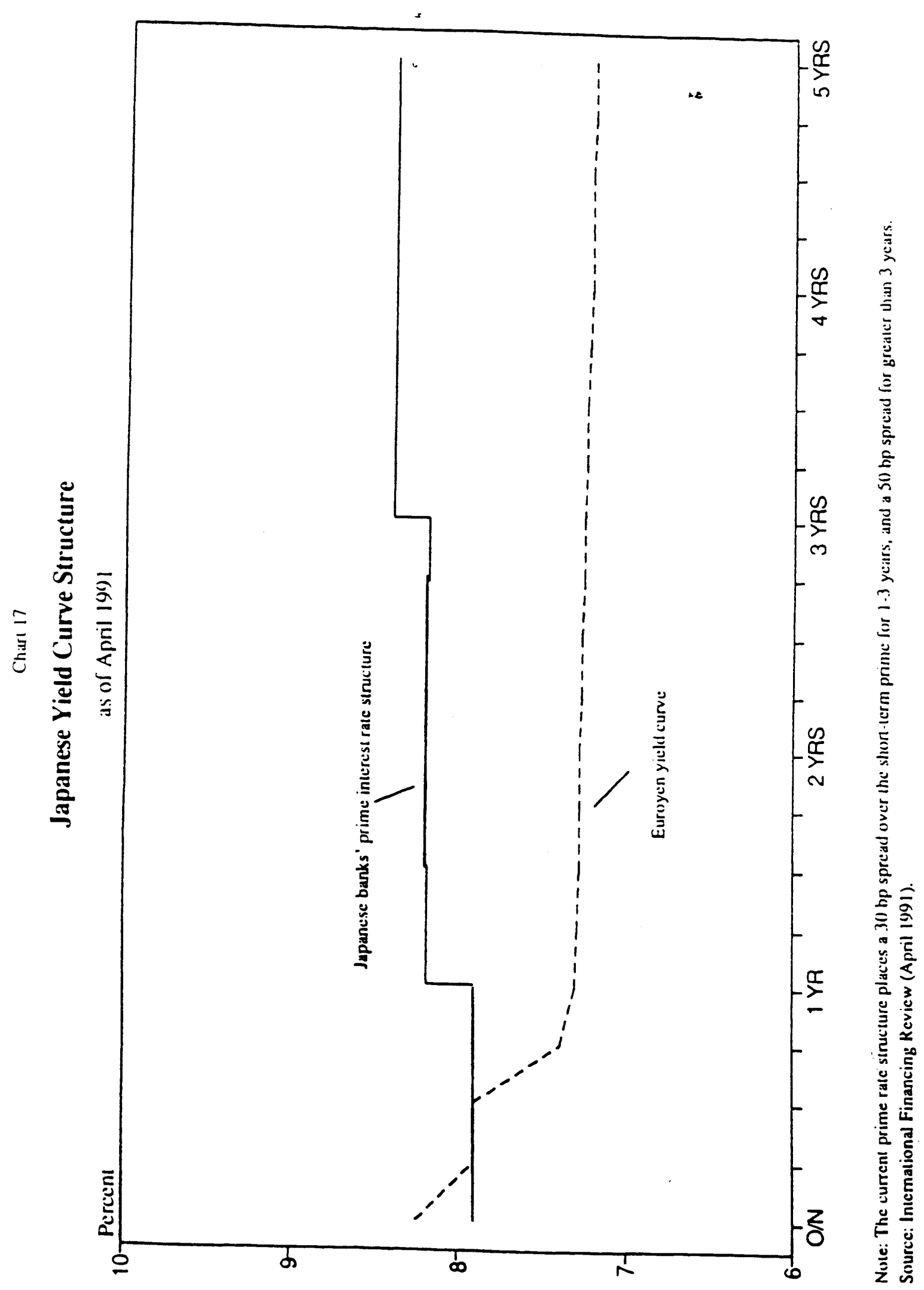




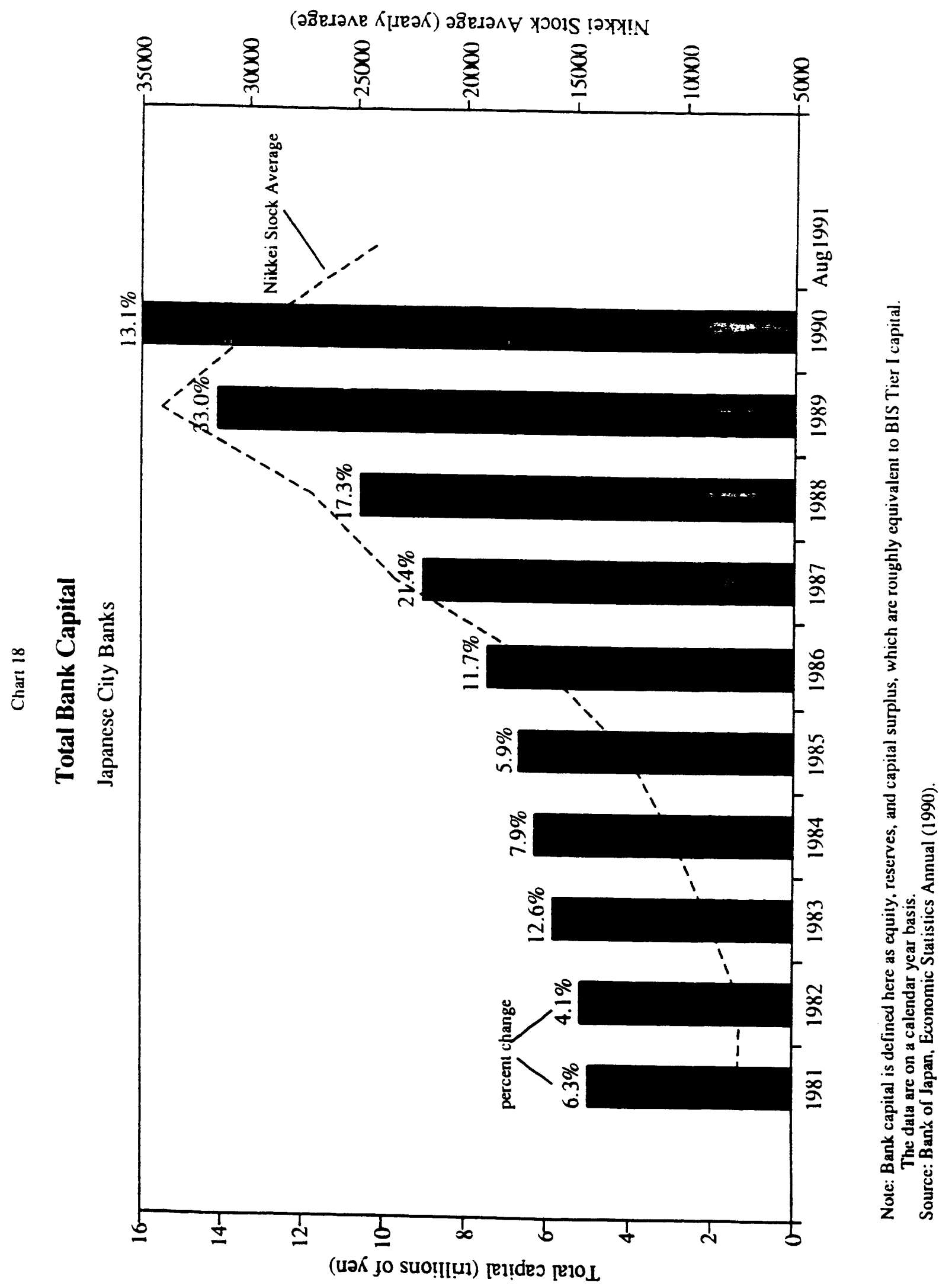




\section{Chart 19 \\ Japanese Bank Capital}

(a)

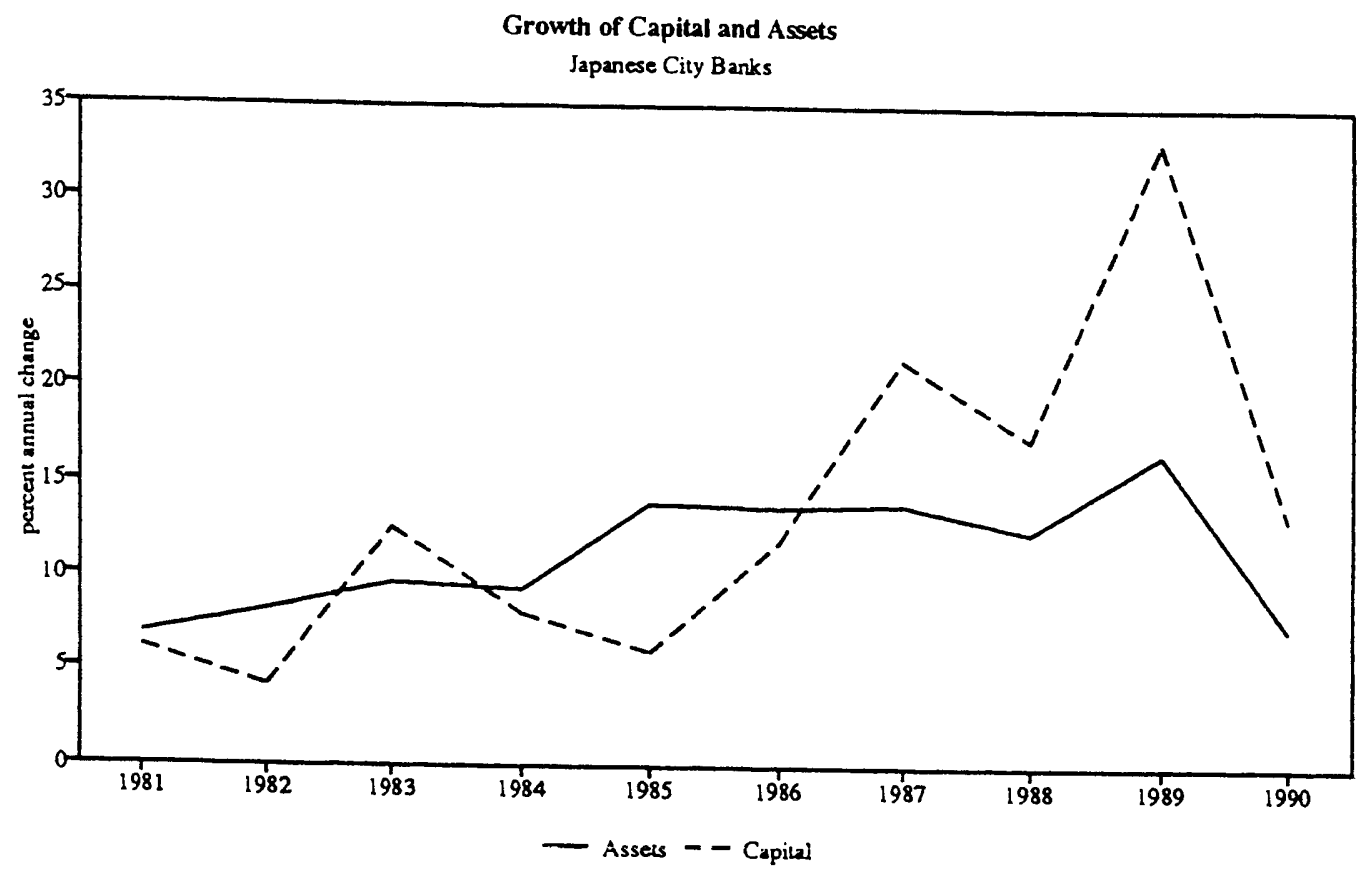

(b)

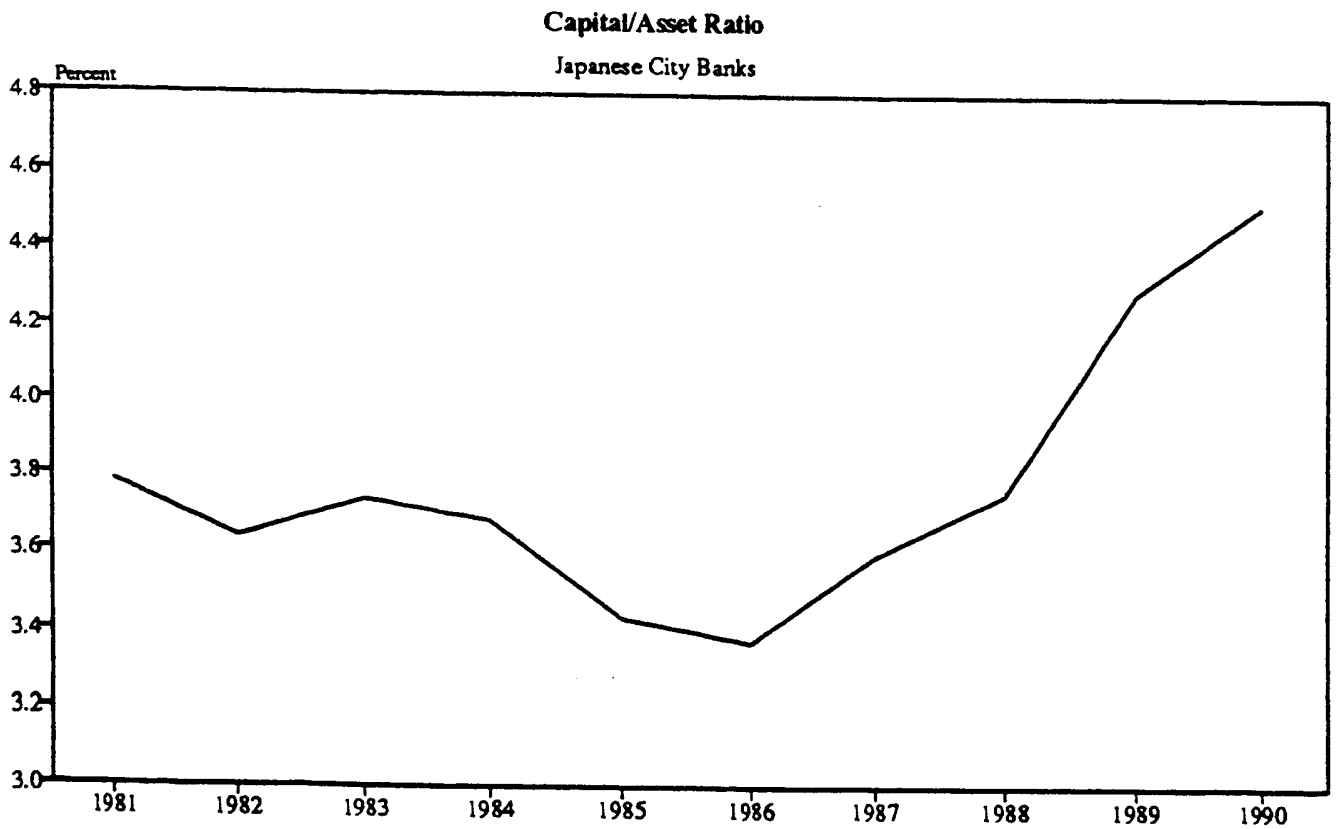

Note: Capinal/anet ratio is defined here as sirmply totel capital (i.e., equity. reserves, and capital surplus) divided by toul assets. Source: Benk of Jamer Economic Stany Bis capital sdoquecy natio. 


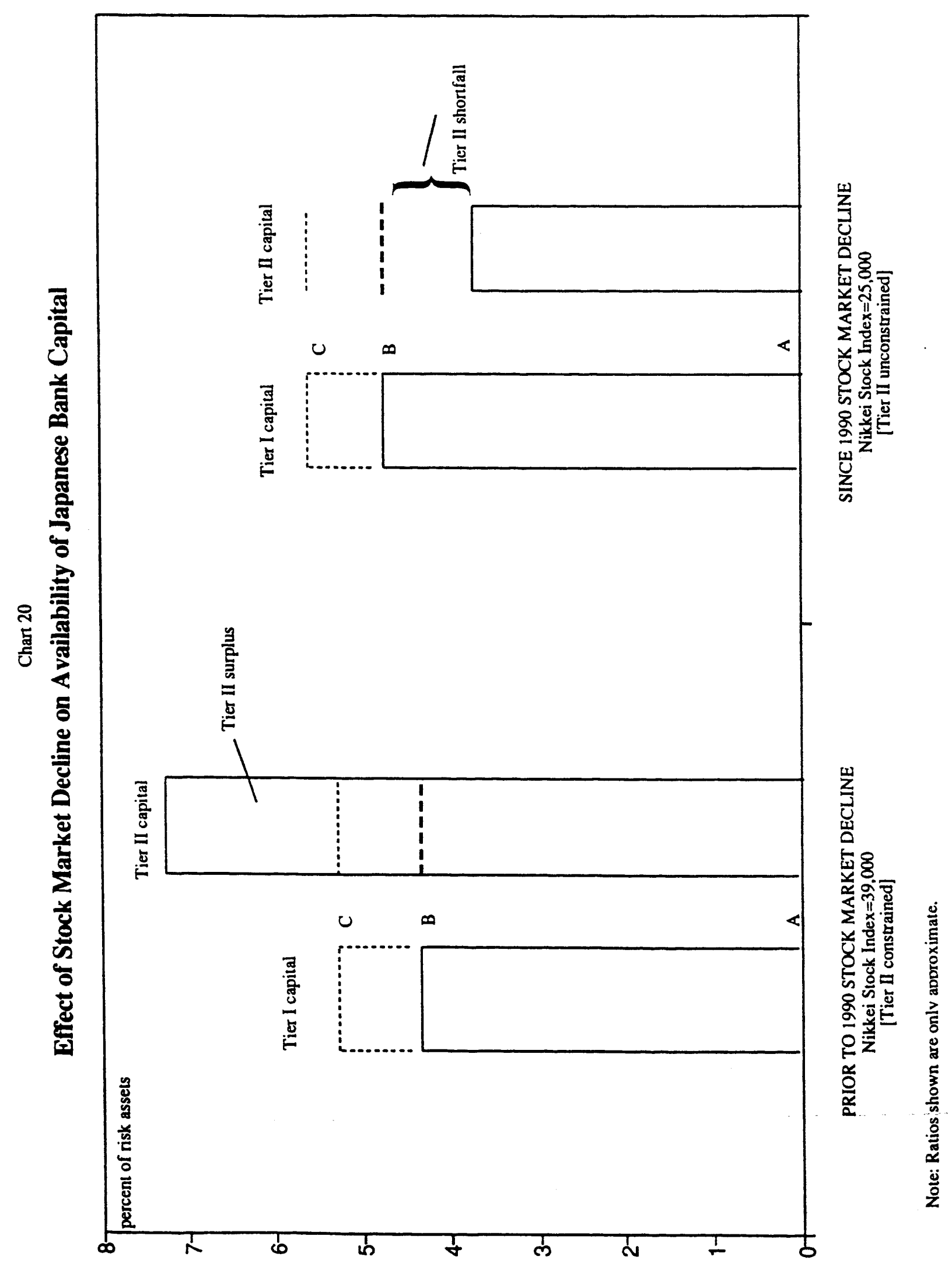


Chart 21

Effects of the Japanese Stock Market

(a)

Capital Gains on the Sale of Securities

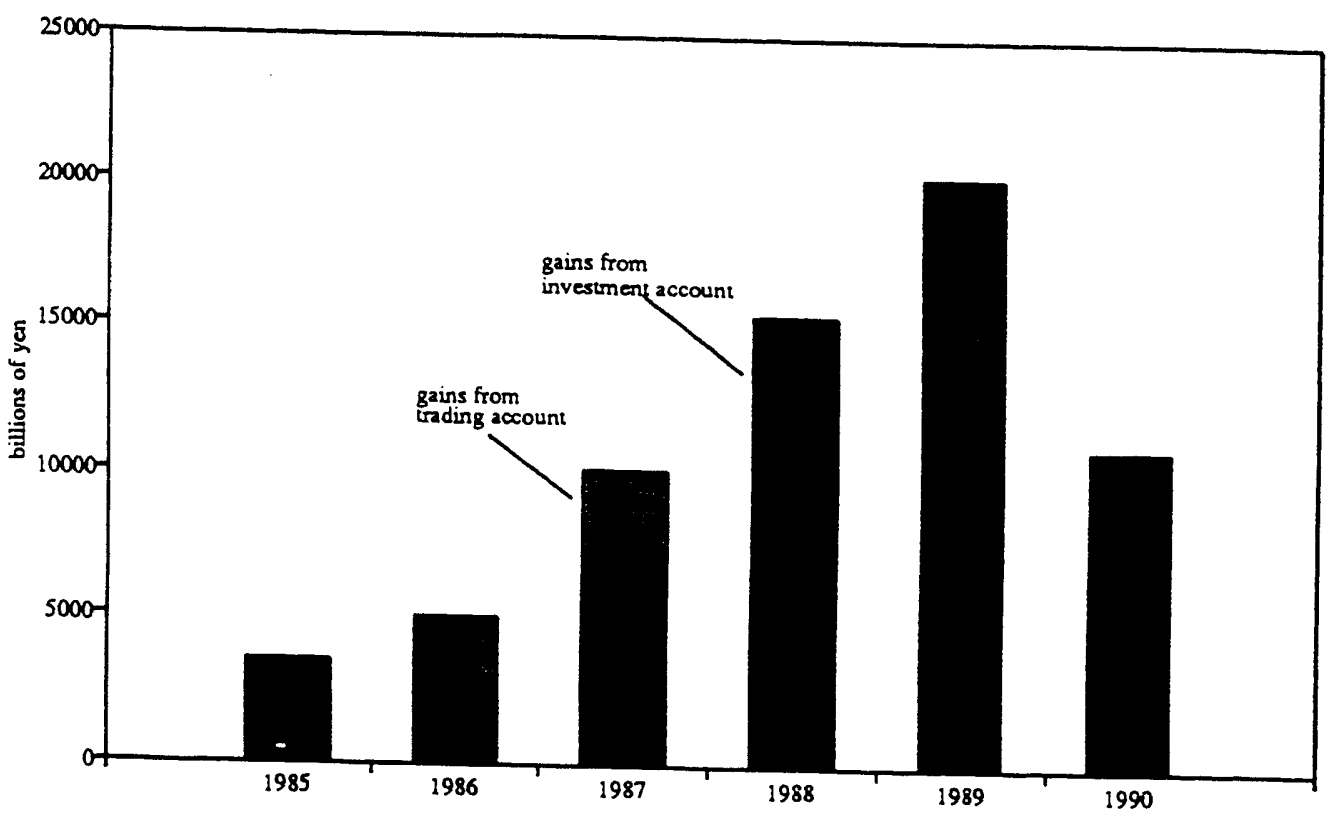

Note: The Japanese diatinetion between invesumers account and tading account securities is similar in nature to that in the United States

(b)

Equity Financing
City Banks

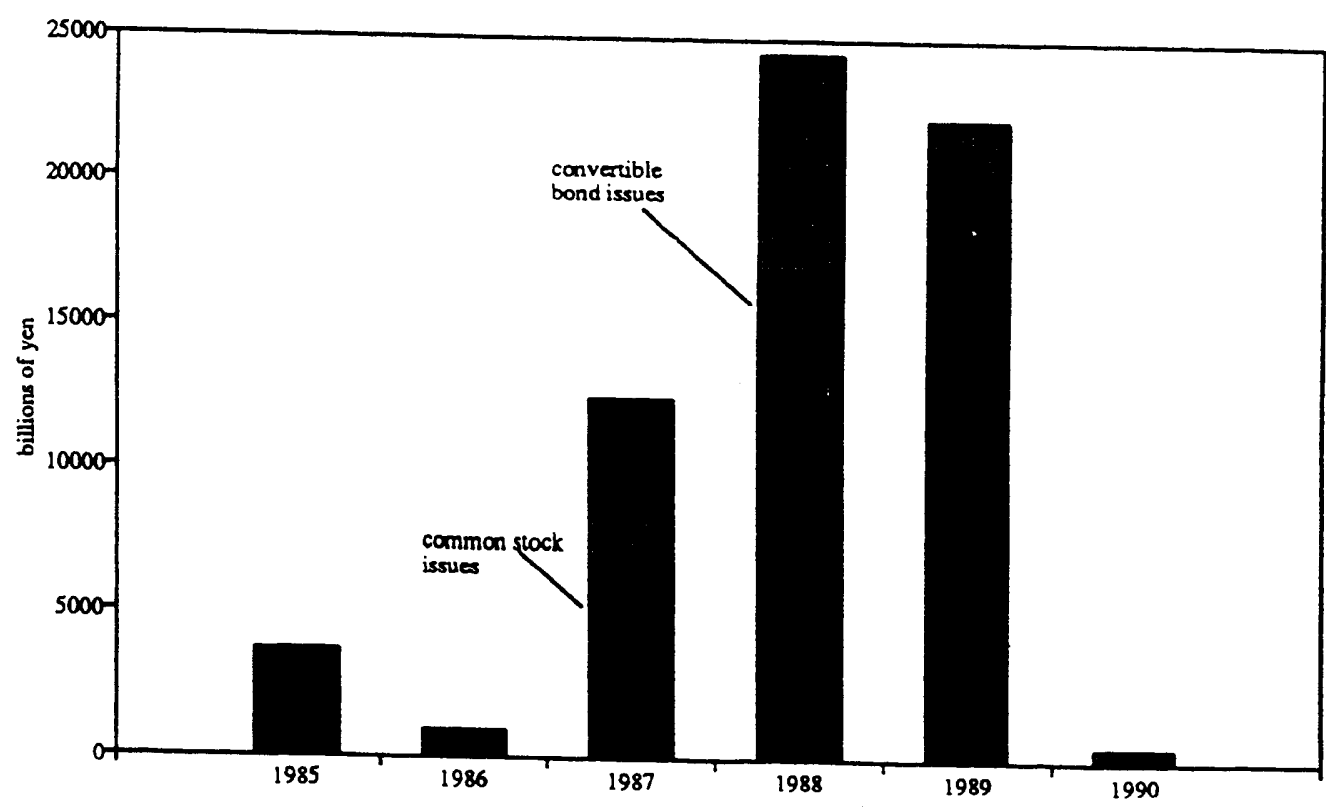

Not: Equiry is nived through converible bond issues upan canversion of the bond into comman srock. Source: Bent of Japen, Speciel Puper No. 206 (September 1991). 


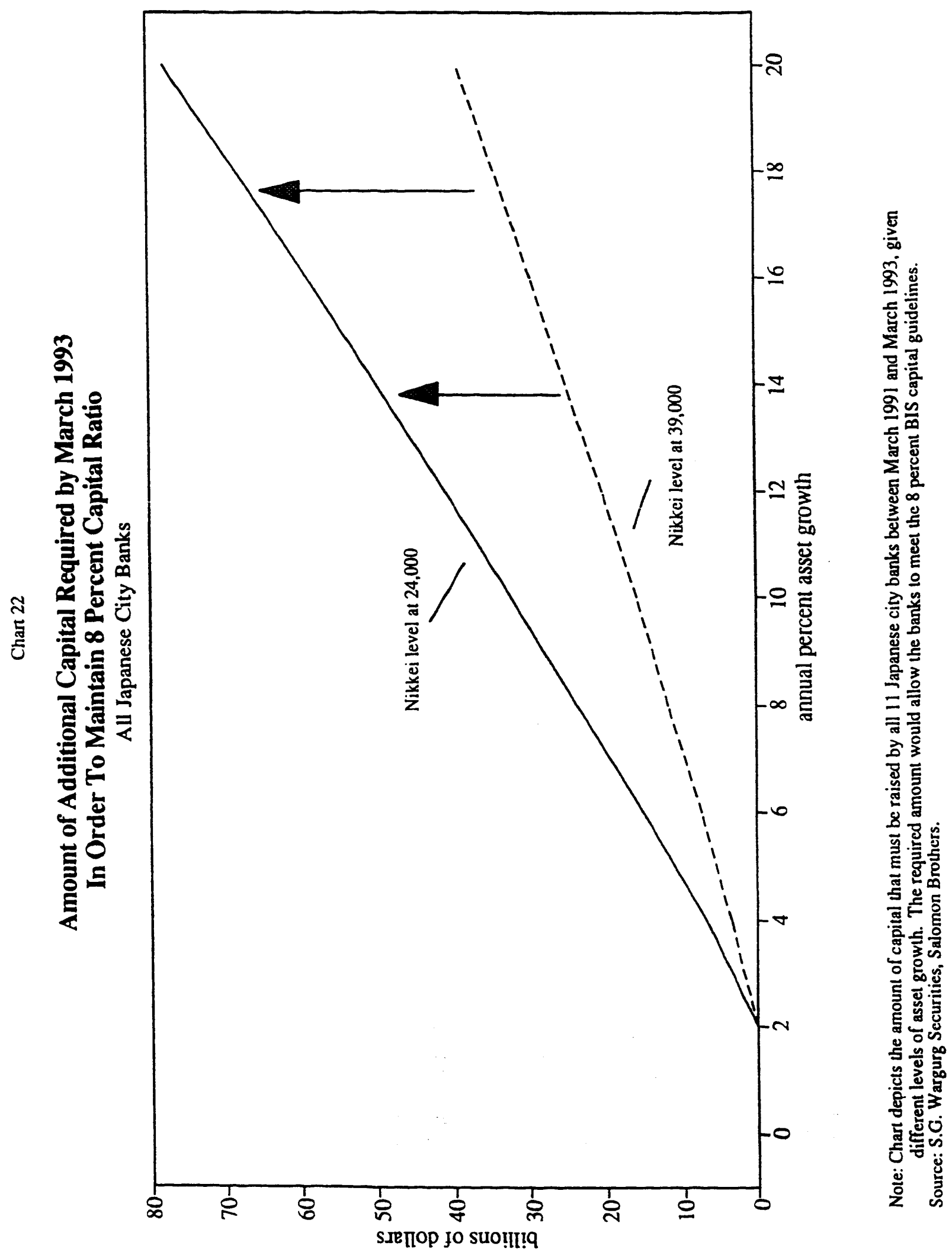



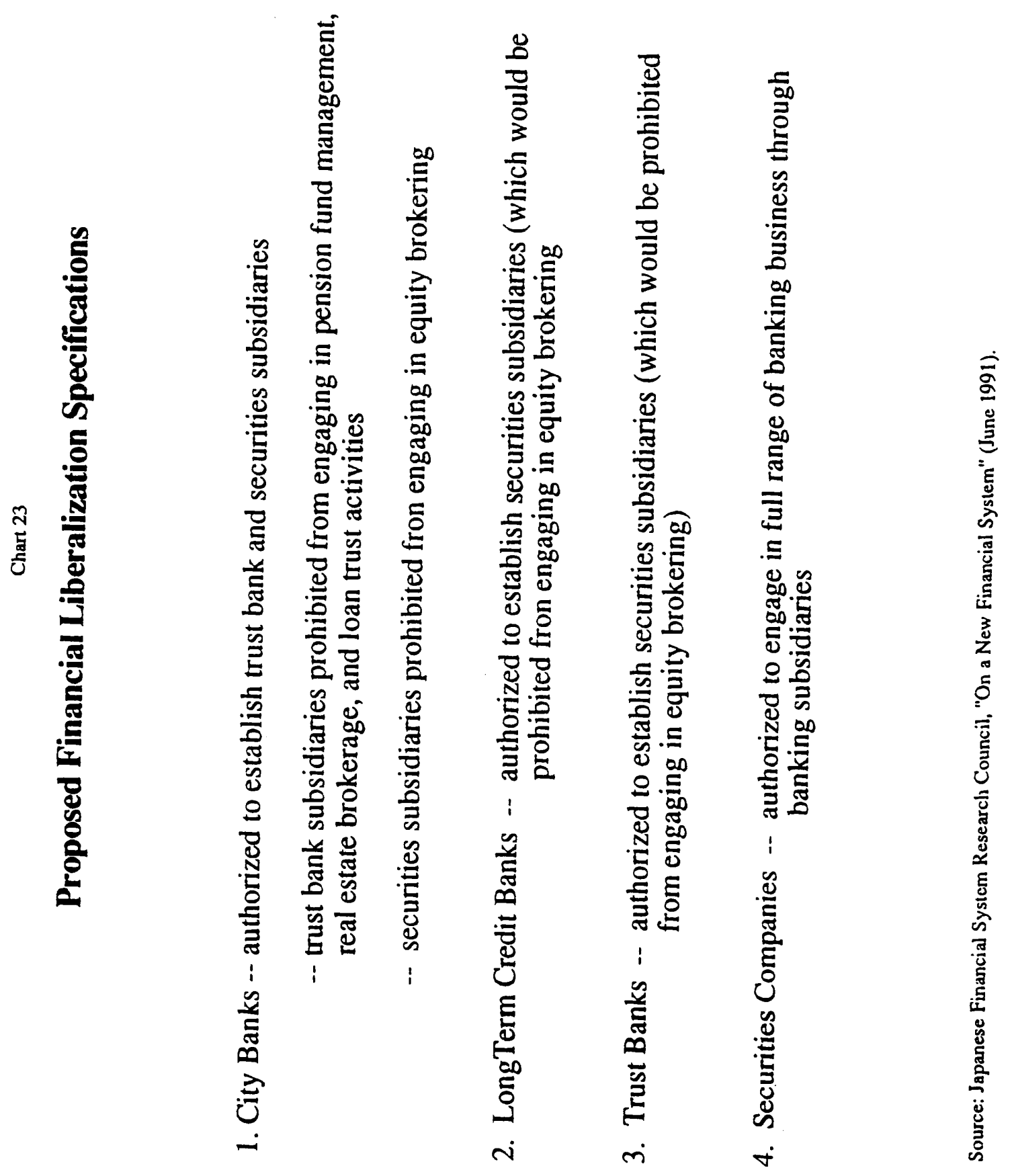
IFDP

NUMBER

419

418

417

416

410

409

408

407

406

405
International Finance Discussion Papers

$$
\frac{\text { TITLES }}{1991}
$$

\section{A Primer on the Japanese Banking System}

Did the Debt Crisis Cause the Investment Crisis?

External Adjustment in Selected Developing Countries in the 1990s

Did the Debt Crisis or the Oil Price Decline Cause Mexico's Investment Collapse?

Cointegration, Exogeneity, and Policy Analysis: An Overview

The Usefulness of $\mathrm{P}^{*}$ Measures for Japan and Germany

Comments on the Evaluation of Policy Models

Parameter Constancy, Mean Square Forecast Errors, and Measuring Forecast Performance: An Exposition, Extensions, and Illustration

Explaining the Volume of Intraindustry Trade: Are Increasing Returns Necessary?

How Pervasive is the Product Cycle? The Empirical Dynamics of American and Japanese Trade Flows

Anticipations of Foreign Exchange Volatility and Bid-Ask Spreads

A Re-assessment of the Relationship Between Real Exchange Rates and Real Interest Rates: 1974 - 1990

Argentina's Experience with Parallel

Exchange Markets: 1981-1990

PC-GIVE and David Hendry's Econometric

Me thodology

EMS Interest Rate Differentials and Fiscal

Policy: A Model with an Empirical

Application to Italy

\section{$\underline{\operatorname{AUTHOR}(\mathbf{s})}$}

Allen B. Frankel Paul B. Morgan

Andrew M. Warner

William L. Helkie David H. Howard

Andrew M. Warner

Neil R. Ericsson

Linda S. Kole Michael P. Leahy

Clive W.J. Granger Melinda Deutsch

Neil R. Ericsson

Donald Davis

Joseph E. Gagnon Andrew K. Rose

Shang-Jin Wei

Hali J. Edison B. Dianne Pauls

Steven B. Kamin

Neil R. Ericsson Julia Campos

Hong-Anh Tran

R. Sean Craig

Please address requests for copies to International Finance Discussion Papers, Division of International Finance, Stop 24, Board of Governors of the Federal Reserve System, Washington, D.C. 20551. 
IFDP

NUMBER

404

403

402

401

400

399

398

397

396

395

394

393

392

391

390

389
International Finance Discussion Papers

$$
\text { TITLES }
$$$$
1991
$$

$\underline{\operatorname{AUTHOR}(s)}$

Lois E. Stekler

The Statistical Discrepancy in the U.S. International Transactions Accounts: Sources and Suggested Remedies

In Search of the Liquidity Effect

Exchange Rate Rules in Support of Disinflation Programs in Developing Countries

The Adequacy of U.S. Direct Investment Data

Determining Foreign Exchange Risk and Bank Capital Requirements

Precautionary Money Balances with

Aggregate Uncertainty

Using External Sustainability to Forecast

the Dollar

Terms of Trade, The Trade Balance, and Stability: The Role of Savings Behavior

The Econometrics of Elasticities or the Elasticity of Econometrics: An Empirical Analysis of the Behavior of U.S. Imports

Expected and Predicted Realignments: The FF/DM Exchange Rate during the EMS

Market Segmentation and 1992: Toward a Theory of Trade in Financial Services

$\underline{1990}$

Post Econometric Policy Evaluation

A Critique

Mercantilism as Strategic Trade Policy:

The Anglo-Dutch Rivalry for the East

India Trade

Free Trade at Risk? An Historical Perspective

Why Has Trade Grown Faster Than Income?

Pricing to Market in International Trade: Evidence from Panel Data on Automobiles and Total Merchandise
Eric M. Leeper David B. Gordon

Steven B. Kamin

Lois E. Stekler Guy V.G. Stevens

Michael P. Leahy

Wilbur John Coleman II

Ellen E. Meade

Charles P. Thomas

Michael Gavin

Jaime Marquez

Andrew K. Rose

Lars E. O. Svensson

John D. Montgomery

Beth Ingram

Eric M. Leeper

Douglas A. Irwin

Douglas A. Irwin

Andrew K. Rose

Joseph E. Gagnon

Michael M. Knetter 